\title{
Standardization and Validation of Fluorescence-Based Quantitative Assay to Study Human Platelet Adhesion to Extracellular-Matrix in a 384-Well Plate
}

\author{
Augusto Martins Lima ${ }^{1,2}, * \mathbb{E}$, Damian S. Saint Auguste ${ }^{1,3}$, François Cuenot ${ }^{1}$, Ana C. Martins Cavaco ${ }^{4}(\mathbb{D}$, \\ Tom Lachkar ${ }^{1}$, Cindy Marie Elodie Khawand ${ }^{1}$, Rodrigo A. Fraga-Silva ${ }^{1}$ and Nikolaos Stergiopulos ${ }^{1}$ \\ 1 Laboratory of Hemodynamics and Cardiovascular Technology (LHTC), Institute of Bioengineering, \\ École Polytechnique Fédérale de Lausanne, 1015 Lausanne, Switzerland; damian.stauguste@gmail.com (D.S.S.A.); \\ francois.cuenot@epfl.ch (F.C.); tom.lachkar@epfl.ch (T.L.); khawand.cindy@gmail.com (C.M.E.K.); \\ rodrigo.fragasilva@epfl.ch (R.A.F.-S.); nikolaos.stergiopulos@epfl.ch (N.S.) \\ 2 Institute of Bioengineering, École Polytechnique Fédérale de Lausanne Station 09, MED 3.2924, \\ CH-1015 Lausanne, Switzerland \\ 3 Laboratory for Orthopaedic Technology, Institute for Biomechanics, Swiss Federal Institute of Technology Zurich, \\ 8093 Zurich, Switzerland \\ 4 Luis Costa Lab, Instituto de Medicina Molecular, Faculdade de Medicina da Universidade de Lisboa, \\ 1649-028 Lisboa, Portugal; anacavaco@medicina.ulisboa.pt \\ * Correspondence: augusto.martinslima@epfl.ch
}

Received: 13 August 2020; Accepted: 3 September 2020; Published: 7 September 2020

\begin{abstract}
Platelets play a crucial role in the immunological response and are involved in the pathological settings of vascular diseases, and their adhesion to the extracellular matrix is important to bring leukocytes close to the endothelial cells and to form and stabilize the thrombus. Currently there are several methods to study platelet adhesion; however, the optimal parameters to perform the assay vary among studies, which hinders their comparison and reproducibility. Here, a standardization and validation of a fluorescence-based quantitative adhesion assay to study platelet-ECM interaction in a high-throughput screening format is proposed. Our study confirms that fluorescence-based quantitative assays can be effectively used to detect platelet adhesion, in which BCECF-AM presents the highest sensitivity in comparison to other dyes.
\end{abstract}

Keywords: platelet adhesion; extracellular matrix; fluorescence-based quantitative assay; BCECF-AM; 384-well plate; high-throughput screening assay

\section{Introduction}

Platelet adhesion is a crucial step in bleeding control and in the thrombosis process. Although circulating platelets show no interaction between them, neither with the internal surface of normal vessels, platelets promptly adhere to exposed extracellular matrix (ECM) proteins upon vascular injury or in pathological settings [1]. Therefore, the balance between hemostasis and thrombosis depends on platelet-ECM interaction: inefficient adhesion leads to bleeding, whereas excessive adhesion followed by platelet activation can prompt thrombus formation [2]. Upon endothelial cell damage, depending on the depth of the injury, platelets come into contact with different ECM constituents [2]. Interestingly, platelets can also adhere to damaged endothelial cells [3], although ECM is their main adhesive substrate. Interaction with ECM leads to platelet rapid activation and prothrombotic factors release, which recruit additional platelets from the bloodstream and promotes platelet aggregation. Platelet adhesion is an initial and crucial step of the coagulation cascade which prevents posttraumatic blood loss [4]. However, uncontrolled thrombus formation can lead to vascular occlusion, ischemia, and if 
located in coronary and cerebral arteries, myocardial infarction and ischemic stroke, respectively [5-7]. Furthermore, platelet adhesion might also influence atherosclerotic plaque progression and stability during the development of atherosclerosis [6].

Vessels are lined by endothelium, and beneath this layer rests the basement membrane, which contains type IV collagen, laminins, nidogens, and perlecan [8]. While the predominant isoforms in vascular basement membranes are nidogen 2 and laminins- 411 and -511 , in the interstitium surrounding the vessels, fibrillar collagen types I, III, and V are the most prominent [9]. Other adhesive proteins, such as von Willebrand factor (vWF), fibronectin, vitronectin, and fibrinogen, are present in plasma and in platelet $\alpha$-granules [10]. For instance, fibrinogen and vitronectin although not synthesized by vascular cells, are potentially relevant thrombogenic substrates as they immobilize onto ECM at sites of injury, being incorporated in the thrombus [11]. Thrombogenic substrates encountered by platelets are determined by the injury degree and depend on the vessel type, influencing platelet adhesion efficiency [10]. Damage to the endothelial layer exposes type IV collagen, laminins, vWF, and fibronectins, whereas more extensive injuries reaching the smooth muscle layer or interstitial ECM expose fibrillar collagens, elastin and microfibrils [2,12]. Furthermore, platelets adhesion capacity to ECM proteins varies, which might also influence the adhesion strength and efficiency [10].

Platelet adhesion to ECM proteins is facilitated by the synergistic function of several platelet receptors, which are essential for the initial adhesion and the subsequent platelet activation and aggregation [6]. The main signals triggered during platelet activation in response to ECM proteins arise from receptors such as glycoprotein (GP) VI, together with integrin $\alpha 2 \beta 1$, both mainly binding to collagen $[6,13]$. Full platelet activation is further facilitated by the transient interaction between platelet-specific GPIb $\alpha$ and vWF [6,13]. Following platelet adhesion and activation, aggregation is enabled by integrin $\alpha \mathrm{IIb} \beta 3$, which changes its ligand binding properties and acquires the ability to bind soluble adhesive proteins, including fibrinogen and vWF [6]. Gene-targeted mouse models were crucial in understanding the relative function of the different platelet receptors. It confirms the importance of adhesion receptors such as GPIb $\alpha$ or integrin $\alpha \operatorname{Ilb} \beta 3$ in thrombus formation, whereas the function of receptors, such as GPVI, seems to be regulated by the severity of injury, type of vessel injured, and generated signaling pathways [14]. Overall the thrombus is stabilized by platelets interacting with collagen present in the vessel ECM during adhesion, and by fibrinogen/fibrin bound-activated platelets during aggregation [6].

Vascular diseases are some of the major clinical problems in the developed world [5,15], and given the relevance of platelets in these pathologies, the understanding of platelets adhesion to the ECM is an important topic of research. Furthermore, new evidences highlight platelet adhesive properties as central to a variety of pathophysiological processes such as inflammation [16], immune-mediated host defense [17], and cancer metastasis [18].

Several methodologies to measure platelet adhesion have been described $[4,19,20]$; however, there is no standard test, which impairs comparison of results from different studies, contributing to the lack of reproducibility in science. Increasing recognition of the inability to replicate the majority of fundamental, biomedical, and preclinical research findings presented in high-profile journals, emphasizes the problem of irreproducibility [21]. Therefore, in the present work a standardization and validation of a fluorescence-based quantitative adhesion assay to study platelet-ECM interaction using a 384-well plate is proposed.

\section{Results}

\subsection{Assay Optimization}

\subsubsection{Assay Linearity}

Assay linearity was calculated by measuring the adhesion to plastic of different concentrations of BCECF-stained human washed platelets. In the proposed assay, the fluorescence signal increased in a platelet concentration-dependent manner (fluorescent units: $2 \times 10^{4}=16,013 \pm 2736$; 
$4 \times 10^{4}=26,115 \pm 5442 ; 8 \times 10^{4}=56,809 \pm 12,000 ; 1.6 \times 10^{5}=104,408 \pm 20,797-R^{2}=0.9971$, Figure 1 A). In addition, $4 \times 10^{4} / \mu \mathrm{L}$ was the minimal platelet concentration necessary to detect significant changes in platelet adhesion to collagen-I (fluorescent units: BSA $=4671 \pm 627$ vs. Col-I $=18,175 \pm 4642$ ) and no statistical differences were found among the groups with platelet concentration of $2 \times 10^{4} / \mu \mathrm{L}$ (fluorescent units: BSA $=4588 \pm 636$ vs. Col-I $=10,667 \pm 5213$, Figure 1B). The optimal concentration of BCECF-AM was also tested by measuring the platelet adhesion to collagen-I. As shown in the Figure $1 \mathrm{C}$, the fluorescence signal was significantly increased on adherent platelets stained with $4 \mu \mathrm{g} / \mathrm{mL}$ (fluorescent units: BSA $=5146 \pm 669$ vs. Col- $\mathrm{I}=20,464 \pm 5817$ ) and $8 \mu \mathrm{g} / \mathrm{mL}$ (fluorescent units: $\mathrm{BSA}=7472 \pm 1064 \mathrm{vs}$. Col-I $=23,361 \pm 5291$ ) of BCECF-AM. Interestingly, at high concentrations of BCECF-AM $(16 \mu \mathrm{g} / \mathrm{mL})$, there was no statistical difference between platelet adhesion to collagen-I compared to non-coated wells (fluorescent units: BSA $=8590 \pm 2653$ vs. Col-I $=19,069 \pm 5560$ ). These results demonstrate the feasibility of platelet adhesion measurement using BCECF-AM and confirm that platelet and BCECF-AM concentrations are important parameters to detect statistical differences between platelet adhesion to ECM-coated and non-coated wells.
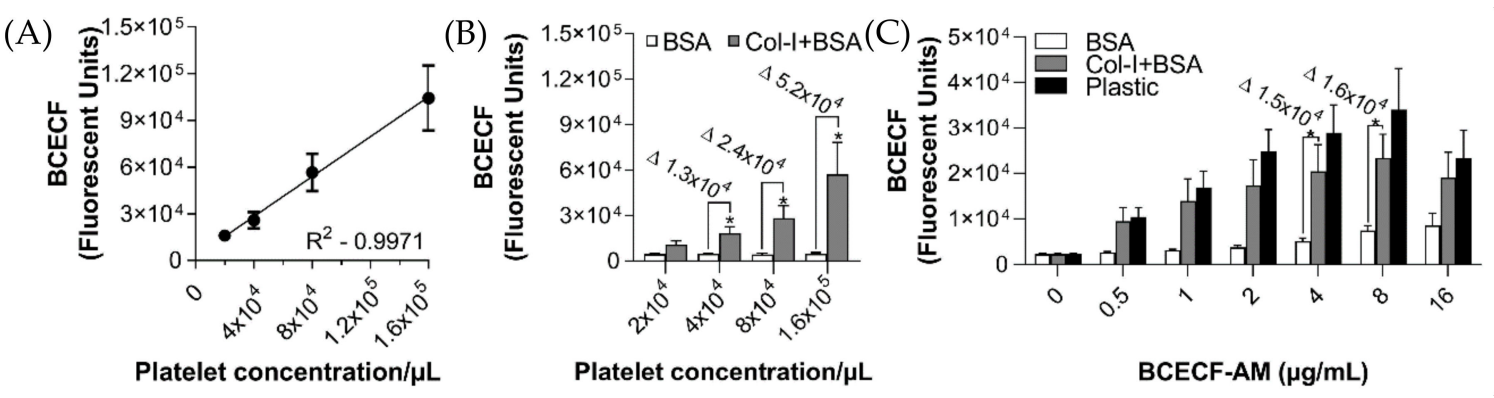

Figure 1. Platelet adhesion assay linearity in a 96-well plate. 96-well microplates were coated with collagen-I $(8 \mu \mathrm{g} / \mathrm{mL}$ in $50 \mu \mathrm{L})$ or incubated with distillated water for $1 \mathrm{~h}$ at $37^{\circ} \mathrm{C}$. After blocking the wells with BSA $(0.03 \%)$, different concentrations of human washed platelets $\left(2 \times 10^{4}\right.$ to $1.6 \times 10^{5} / \mu \mathrm{L}$ in $100 \mu \mathrm{L}$ ) were added, followed by incubation for $1 \mathrm{~h}$ at $37^{\circ} \mathrm{C}$. Next, non-adherent platelets were removed, and adherent platelets were incubated with BCECF-AM $(0.25$ to $16 \mu \mathrm{g} / \mathrm{mL}$ in $50 \mu \mathrm{L})$ for $30 \mathrm{~min}$ at $37^{\circ} \mathrm{C}$. Fluorescence intensity was measured using a plate reader (VictorX, PerkinElmer, Waltham, MA, USA). (A) Assay linearity $\left(\mathrm{R}^{2}=0.9971\right)$ was calculated by measuring the fluorescence signal of different platelet concentrations adhered to plastic. (B) The optimum platelet concentration to obtain statistical differences between non-coated (white bars) and collagen-I-coated wells (grey bars) was assessed by using different platelet concentrations. $\Delta$ represents delta: (Col-I+BSA) - (BSA). (C) The optimal concentration of BCECF-AM was assessed by comparing the fluorescence signal of adherent platelets $\left(8 \times 10^{4} / \mu \mathrm{L}\right.$ in $\left.100 \mu \mathrm{L}\right)$ on non-coated wells (white bars) and collagen-I-coated wells (grey bars). Plastic was used as positive control (black bars). $\Delta$ represents delta (Col-I+BSA) - (BSA). Fluorescence intensity of collagen-coated surfaces blocked with BSA was compared to BSA alone for each experimental group by $t$-test $\left({ }^{*} p<0.05\right.$, data are mean \pm SEM; $\left.n=4\right)$.

\subsubsection{Non-Specific Binding Blocking}

BSA has been widely used to prevent the non-specific binding of cells to different surfaces, including polystyrene, assuring the specificity of cell adhesion to the ECM. However, the BSA concentration varies largely between experimental protocols, as well as the type of plate used. Therefore, we tested the optimal BSA concentration to prevent non-specific binding using 3 different microplates (Figure 2). In this experimental setup, the following microplates were used: (1) Invitrogen ${ }^{\mathrm{TM}}$ (44-2404-21) has the MaxiSorp ${ }^{\circledR}$ technology with a highly charged polystyrene surface with high affinity for molecules with polar or hydrophilic groups; (2) Greiner Bio-one (655180) and (3) Corning (353072) have polystyrene surface wells treated with plasma gas, which increases hydrophobicity. To block non-specific platelet binding to the wells surface, different BSA concentrations were used $(0.00075$ to $4 \%-\mathrm{BSA}$ ) and all concentrations reduced significantly the platelet adhesion to the plastic of the Invitrogen $^{\mathrm{TM}}$ (44-2404-21) plate with the MaxiSorp ${ }^{\circledR}$ technology. Furthermore, $0.03 \%$ BSA had the best 
blocking effect compared to all other BSA concentrations (fluorescent units: $0 \%$ BSA $=30,404 \pm 4713$ vs. $0.03 \% \mathrm{BSA}=6184 \pm 400$ ). Surprisingly, although there was a decreasing tendency of platelet adhesion to plastic at $0.03 \%$ BSA concentration, no statistical difference was found in neither BSA concentrations used to block Greiner Bio-one (655180) or Corning (353072) plates. These results clearly show that BSA low concentrations inhibit platelet adhesion to plastic of Invitrogen ${ }^{\mathrm{TM}}$ (44-2404-21) plate with the MaxiSorp ${ }^{\circledR}$ technology.
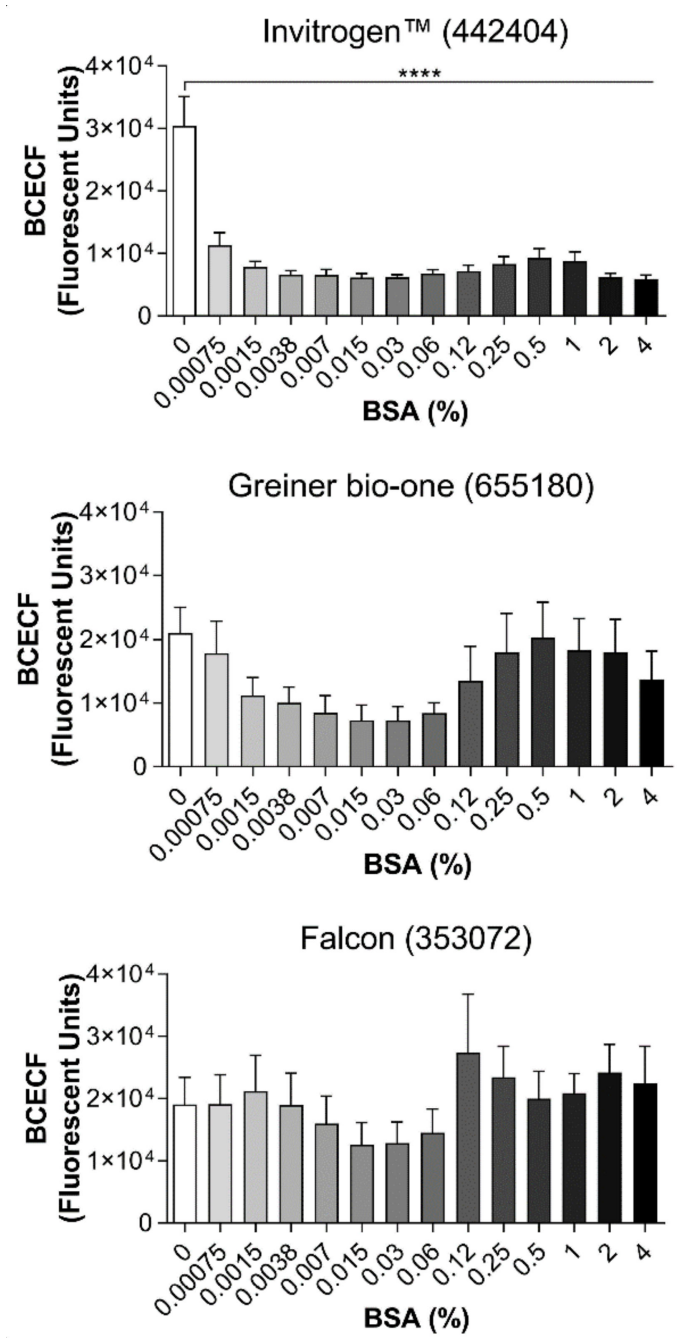

Figure 2. BSA blocking on different types of 96-well plates. BSA was used to prevent non-specific adhesion of platelets to the plastic. To find the optimum conditions, 3 types of 96-well plates (Invitrogen ${ }^{\mathrm{TM}}$-442404; Greiner Bio-one-655,180 and Falcon-353072) were blocked with different concentrations of BSA $(0.00075$ to $4 \%$ in $50 \mu \mathrm{L})$ for 1 hour at $37^{\circ} \mathrm{C}$. Next, human washed platelets $\left(8 \times 10^{4} / \mu \mathrm{L}\right.$ in $\left.100 \mu \mathrm{L}\right)$ were added, followed by incubation for $1 \mathrm{~h}$ at $37^{\circ} \mathrm{C}$. Non-adherent platelets were removed, and adherent platelets were incubated with BCECF-AM $(4 \mu \mathrm{g} / \mathrm{mL}$ in $50 \mu \mathrm{L})$ for $30 \mathrm{~min}$ at $37^{\circ} \mathrm{C}$. Fluorescence intensity was measured using a plate reader (VictorX, PerkinElmer, Waltham, MA, USA). Values were compared to the control condition-without BSA-by one-way ANOVA followed by Dunnett's post hoc test ${ }^{* * * *} p<0.0001$, data are mean \pm SEM; $\left.n=4\right)$.

\subsubsection{Optimal ECM Protein Concentration to Perform Platelet Adhesion Assay}

Platelet adhesion is an important function in response to vascular damage and several ECM proteins are involved in this event, depending on the type and depth of the injury. In order to test the BCECF-AM-based assay capability to measure platelet adhesion, several ECM proteins were tested at different concentrations: fibrinogen, fibronectin, non-fibrillar and fibrillar collagen-I, 
collagen-III, collagen-IV, laminin-411, laminin-511, CRP, and vitronectin (Figure 3). Platelet adhesion was significantly increased on wells coated with fibrinogen, followed by laminin-511, laminin-411, non-fibrillar collagen-I and collagen-IV, in a concentration-dependent manner. Interestingly, at high concentrations, platelet adhesion to fibrinogen was markedly impaired. Platelet adhesion was also detected on fibronectin, fibrillar collagen-I and CRP, only at one specific concentration (fibronectin: $20 \mu \mathrm{g} / \mathrm{mL}$; fibrillar collagen-I: $64 \mu \mathrm{g} / \mathrm{mL}$ and CRP: $10 \mu \mathrm{g} / \mathrm{mL}$ ). No statistical difference on platelet adhesion was detected on wells coated with collagen-III or vitronectin. Altogether these results show the BCEFC-AM-based assay capability to detect human platelet adhesion to the most relevant ECM proteins in vessel damage and thrombus formation.
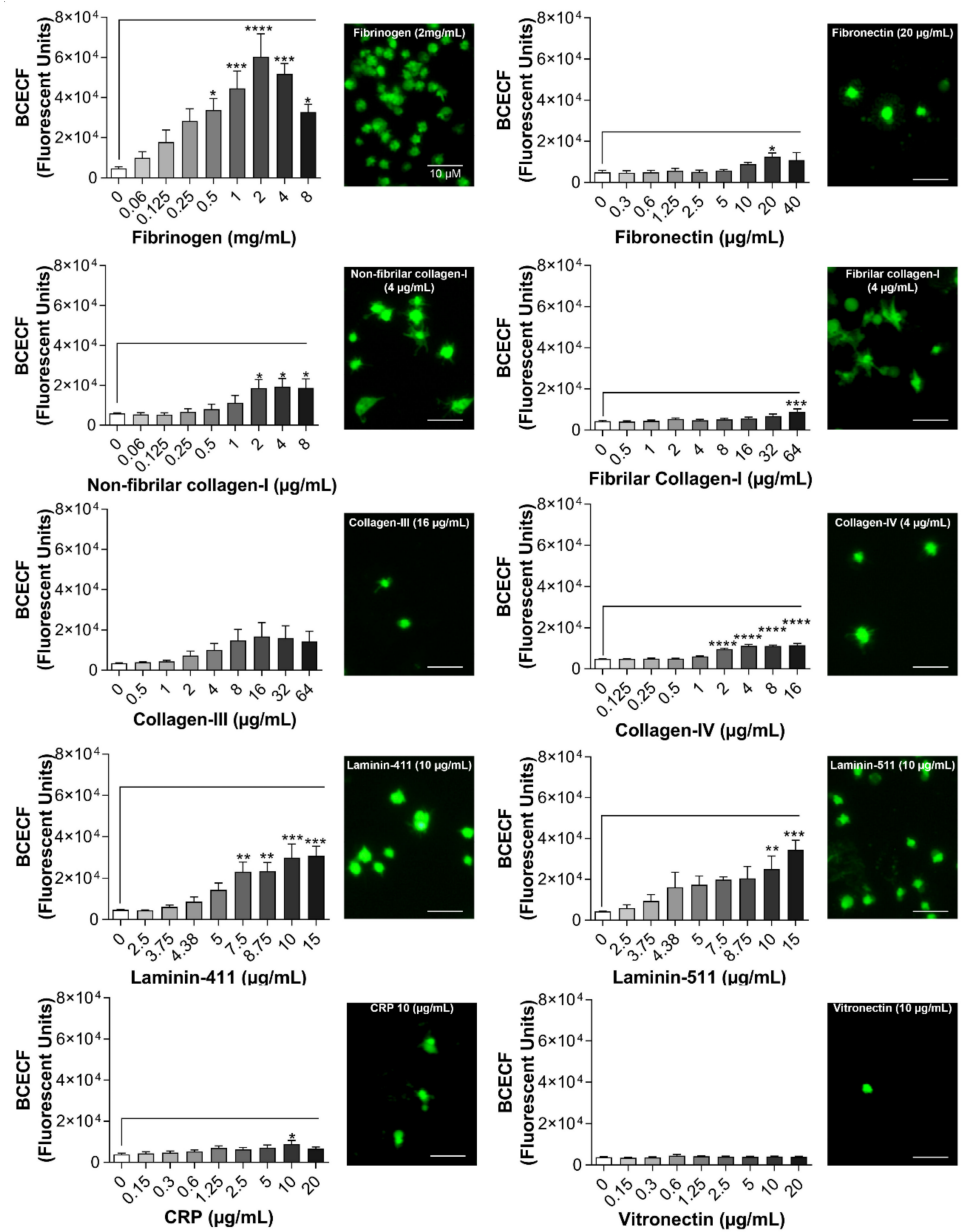

Figure 3. Platelet adhesion on different ECM proteins measured by BCECF-AM. Coating of 96-well microplates with ECM proteins $(50 \mu \mathrm{L})$ was performed for $1 \mathrm{~h}$ at $37^{\circ} \mathrm{C}$. Different proteins and concentrations of ECM were used: fibrinogen $(0.06$ to $8 \mathrm{mg} / \mathrm{mL})$; fibronectin $(0.3$ to $40 \mu \mathrm{g} / \mathrm{mL})$; non-fibrillar collagen-I ( 0.06 to $8 \mu \mathrm{g} / \mathrm{mL})$; fibrillar collagen-I ( 0.06 to $8 \mu \mathrm{g} / \mathrm{mL})$; collagen-III ( 0.5 to $64 \mu \mathrm{g} / \mathrm{mL}$ ); collagen-IV (0.125 to $16 \mu \mathrm{g} / \mathrm{mL})$; laminin-411 (2.5 to $15 \mu \mathrm{g} / \mathrm{mL})$; laminin-511 (2.5 to $15 \mu \mathrm{g} / \mathrm{mL})$; collagen-related peptide (CRP) $(0.15$ to $20 \mu \mathrm{g} / \mathrm{mL})$; vitronectin $(0.15$ to $20 \mu \mathrm{g} / \mathrm{mL})$. In the wells without coating distillated water was added during the coating incubation time. After blocking the wells with BSA $(0.03 \%)$, platelets $\left(8 \times 10^{4} / \mu \mathrm{L}\right.$ in $\left.100 \mu \mathrm{L}\right)$ were added, followed by incubation for $1 \mathrm{~h}$ at $37^{\circ} \mathrm{C}$. Next, non-adherent platelets were removed, and adherent platelets were incubated with BCECF-AM $(4 \mu \mathrm{g} / \mathrm{mL}$ in $50 \mu \mathrm{L})$ for $30 \mathrm{~min}$ at $37^{\circ} \mathrm{C}$. Fluorescence intensity was measured using a plate reader (VictorX, PerkinElmer, Waltham, MA, USA) and images were taken using a fluorescence microscopy (Eclipse Ti2, Nikon, Tokyo, Japan) with a 20× objective (scale bar $10 \mu \mathrm{M})$. Values were compared with the non-coated control condition by one-way ANOVA followed by Dunnett's post hoc test $\left({ }^{*} p<0.05\right.$, ** $p<0.01,{ }^{* * *} p<0.001,{ }^{* * * *} p<0.0001$, data are mean \pm SEM; $n=4$ ). 


\subsection{Assay Validation}

\subsubsection{Comparison between BCECF-AM vs. Calcein-AM and Its Variations}

In order to validate the assay, BCECF-AM-based assay was compared to two other labelling techniques: Calcein-AM (Figure 4) and Sudan Black B (SBB (Supplementary Figure S1). Platelets were pre-stained as previously described by several authors, using Calcein-AM (see Table 1) or SBB [19]. In contrast, the experimental protocol employing BCECF-AM stains the already adherent platelets. For this experimental setup, all techniques were performed with the same platelet, collagen-I and BSA concentrations. In addition, two different approaches were used to detect the platelet adhesion signal: Non-lysed vs. lysed platelets. Surprisingly, only the BCECF-AM technique was capable to detect platelet adhesion with statistical differences between non-coated vs. collagen-I-coated wells (fluorescent units: non-coated wells $=4114 \pm 537 \mathrm{vs} .4 \mu \mathrm{g} / \mathrm{mL}$ collagen-I-coated wells $=38,114 \pm 8061$ ), while for Calcein-AM (Figure 4) no statistical differences were observed between both conditions. In addition, a more robust delta value of the fluorescence signal for the measurements was observed for the non-lysed BCECF-AM labeled platelets. This experiment clearly shows that BCECF-AM is a more accurate technique to measure platelet adhesion compared to Calcein-AM. Interestingly, although a significant difference between non-coated vs. collagen-coated wells was observed when platelets were stained with SBB, platelet aggregates were detected on non-coated wells (supplementary Figure S1).

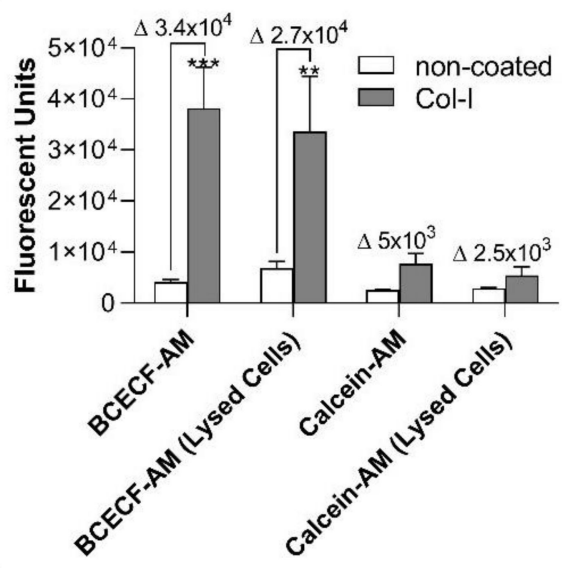

Figure 4. Platelet adhesion detection using different techniques: BCECF-AM vs. Calcein-AM. Coating of 96-well microplates with collagen-I $(4 \mu \mathrm{g} / \mathrm{mL}$ in $50 \mu \mathrm{L})$ or distillated water were performed for $1 \mathrm{~h}$ at $37^{\circ} \mathrm{C}$. After blocking the wells with BSA $(0.03 \%)$, human washed platelets $\left(8 \times 10^{4} / \mu \mathrm{L}\right.$ in $\left.100 \mu \mathrm{L}\right)$ were added, followed by incubation for $1 \mathrm{~h}$ at $37^{\circ} \mathrm{C}$. Next, non-adherent platelets were removed. For the BCECF-AM experimental group, adherent platelets were incubated with BCECF-AM $(4 \mu \mathrm{g} / \mathrm{mL}$ in $50 \mu \mathrm{L})$ for $30 \mathrm{~min}$ at $37^{\circ} \mathrm{C}$. After washing the excess of BCECF-AM, fluorescence intensity was measured using plate reader (VictorX, PerkinElmer, Waltham, MA, USA). In an independent experimental condition, the signal of BCECF-AM was measured after lysing the adhered platelets with lysis buffer. For the experiment using Calcein, AM ( $2 \mu \mathrm{g} / \mathrm{mL})$, platelets were pre-stained following the protocol previous described by several authors (see Table 1). Briefly, PRP obtained by centrifugation of the whole blood was incubated with Calcein-AM $(2 \mu \mathrm{g} / \mathrm{mL})$ for $1 \mathrm{~h}$ at $37^{\circ} \mathrm{C}$. Platelets were then washed as described in the Section 4.2. Fluorescence intensity was measured using plate reader (VictorX, PerkinElmer, Waltham, MA, USA). $\Delta$ represents delta: (Col-I) - (non-coated). Values were compared with the control condition with BSA only (non-coated), by two-way ANOVA followed by Tukey's post hoc test $\left({ }^{* *} p<0.01,{ }^{* * *} p<0.001\right.$, data are mean \pm SEM; $\left.n=4\right)$.

TC-I 15 , a potent $\alpha 2 \beta 1$ integrin inhibitor, was used to test the assay's ability to test different platelet receptor inhibitors and their effect on platelet adhesion. As shown in Figure 5, platelet adhesion on collagen-I-coated wells was markedly reduced by TC-I 15 in a concentration-dependent manner. TC-I 15, at a concentration of $1 \mu \mathrm{M}$, inhibited significantly platelet adhesion to collagen-I (fluorescent 
units: non-treated platelets $=22,390 \pm 5277$ vs. TC-I 15 treated platelets, $1 \mu \mathrm{M}=6633 \pm 815)$ and the dendritic shape with spiky membrane extensions, typically caused by adhesion to collagen-I, was abolished. Taken together, these results demonstrate the relevance of the assay in detecting platelet adhesion inhibition in pharmacological tests.
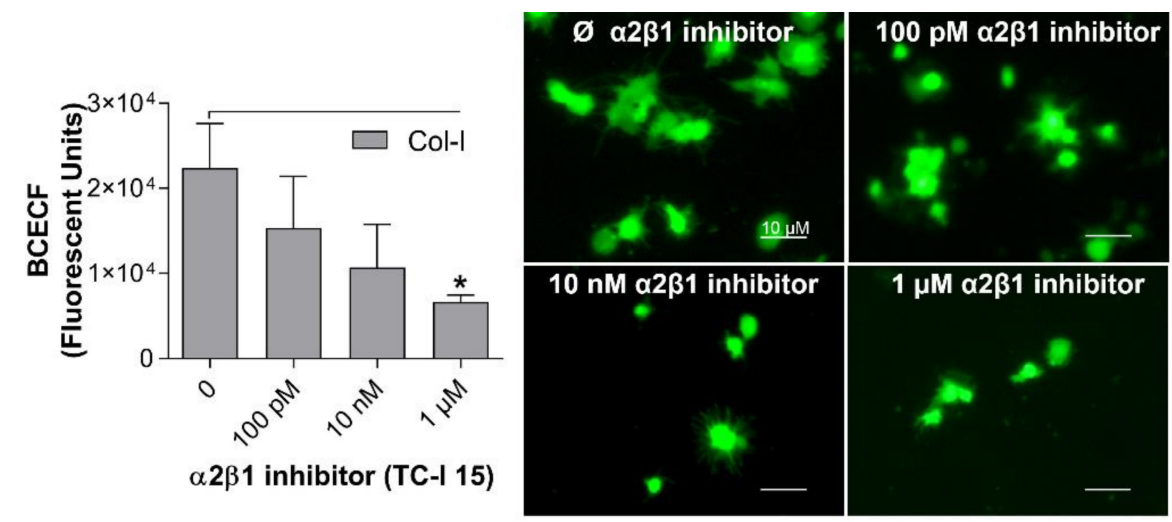

Figure 5. Sensitivity of the optimized assay to detect platelet adhesion inhibition. Coating of 96-well microplates with collagen-I $(4 \mu \mathrm{g} / \mathrm{mL}$ in $50 \mu \mathrm{L})$ or distillated water was performed for $1 \mathrm{~h}$ at $37^{\circ} \mathrm{C}$. After blocking the wells with BSA $(0.03 \%)$, human washed platelets $\left(8 \times 10^{4} / \mu \mathrm{L}\right.$ in $\left.100 \mu \mathrm{L}\right)$ containing different concentrations of TC-I 15, an $\alpha 2 \beta 1$ integrin inhibitor, were added to the coated wells, followed by incubation for $1 \mathrm{~h}$ at $37^{\circ} \mathrm{C}$. Non-adherent platelets were removed, and adherent platelets were incubated with BCECF-AM $(4 \mu \mathrm{g} / \mathrm{mL}$ in $50 \mu \mathrm{L})$ for $30 \mathrm{~min}$ at $37^{\circ} \mathrm{C}$. Fluorescence intensity was measured using a plate reader (VictorX, PerkinElmer). Values were compared to the control group without TC-I 15 by one-way ANOVA followed by Dunnett's post hoc test ${ }^{*} p<0.05$, data are mean $\pm \mathrm{SEM} ; n=4)$. Images were acquired with a fluorescence microscopy (Eclipse Ti2, Nikon, Waltham, MA, USA) with a $20 x$ objective (scale bar $10 \mu \mathrm{M}$ ).

\subsubsection{Z'-Factor Calculation in a 384-Well Plate}

Platelet adhesion to fibrinogen was studied to validate the assay in a 384-well plate. The adhesion response was compared to the results obtained using a 96-well plate. The same fibrinogen, BSA and platelet concentration was used in both plates with a lower final volume for 384-well plate compared to 96-well plate (see Standard Operating Procedure supplemental material). As it is shown on Figure 6, platelet adhesion to fibrinogen on 384-well plate increases in a concentration-dependent manner. The maximal response was obtained at $4 \mathrm{mg} / \mathrm{mL}$ of fibrinogen, and the response was significantly increased compared to BSA coated-wells (concentrations $0.25 \mathrm{mg} / \mathrm{mL}$ to $8 \mathrm{mg} / \mathrm{mL}$ ) (Figure 6A). Similarly to the 96-well plate, platelet adhesion was impaired when high concentration of fibrinogen was used $(8 \mathrm{mg} / \mathrm{mL})$. Although the maximal response varied between both plates (fluorescent units: 384-well plate, $4 \mathrm{mg} / \mathrm{mL}$ fibrinogen $=231,032 \pm 12,022$ vs. 96-well plate, $2 \mathrm{mg} / \mathrm{mL}$ fibrinogen $=60,411 \pm 11326$ ), the pattern of platelet adhesion response was clearly similar, validating the assay also to a 384-well plate.

The $Z^{\prime}$-factor, a statistical parameter that considers the window and variance around high and low assay signals, was used to measure the quality of the assay. Importantly, the $Z^{\prime}$-factor ranges $-\infty$ to 1 and an assay with a score greater than 0.5 is considered robust and appropriate to high-throughput screening [22]. To examine this, fibrinogen $(1 \mathrm{mg} / \mathrm{mL})$ diluted in water was added to half of the 384-well microplate (176 wells_-right side). In the other half, water was added (176 wells-left side). After blocking the wells with BSA, platelet adhesion was measured using BCECF-AM. As shown on Figure $6 \mathrm{~B}$, using a platelet concentration of $8 \times 10^{4} / \mu \mathrm{L}$, an optimal $\mathrm{Z}^{\prime}$-factor value $(<0.5)$ was attained with a 384-well plate (fluorescent units: non-coated wells = mean 17,819 \pm SD 4293 vs. fibrinogen-coated wells, $1 \mathrm{mg} / \mathrm{mL}=$ mean 196,492 \pm SD 14170). 
(A)

(B)
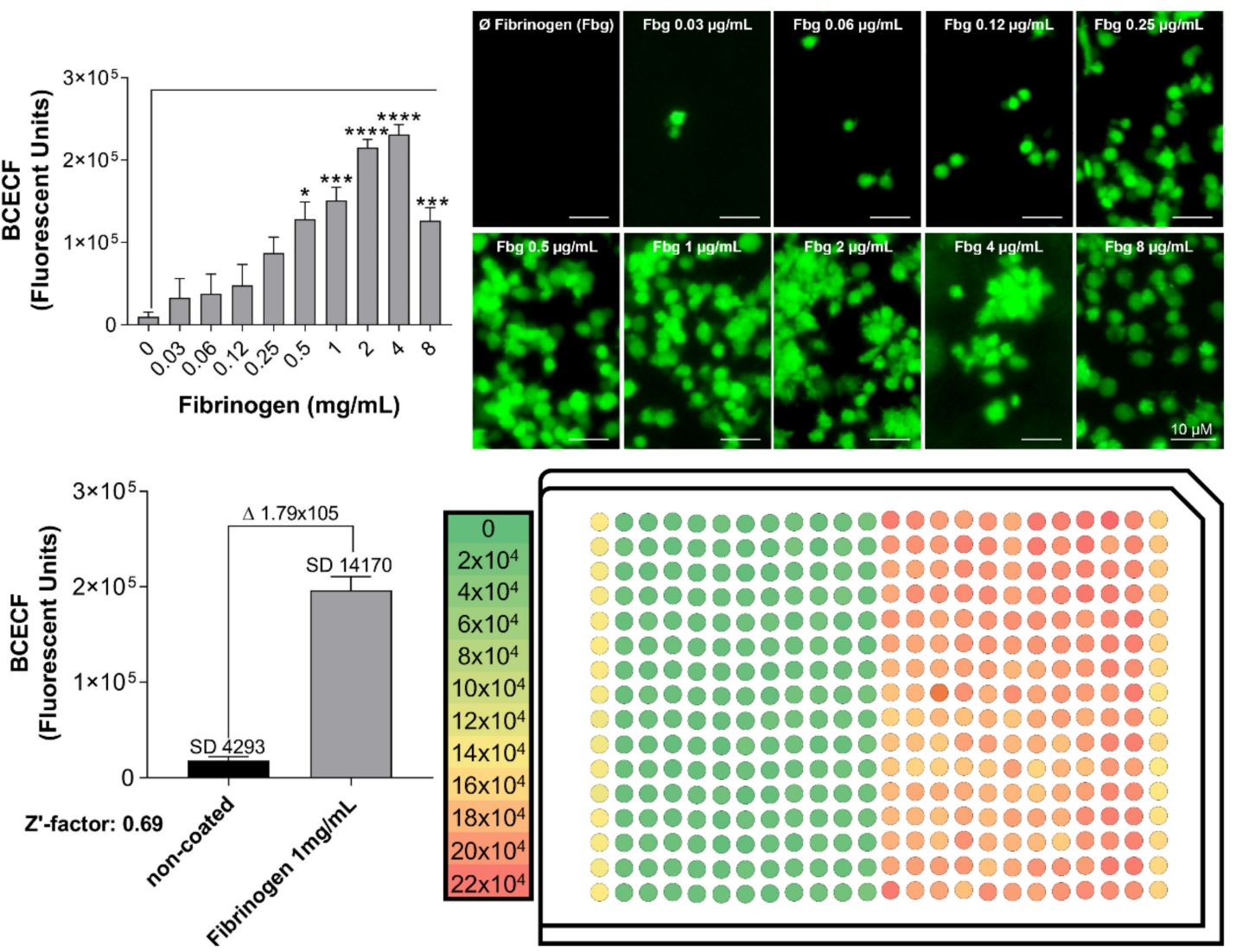

Figure 6. Z'-factor calculation to validate the platelet adhesion assay in a 384-well microplate. (A) Platelet adhesion similarity between 96- and 384-well microplates. Coating of 384-well microplate with different concentrations of fibrinogen ( $\mathrm{Fbg} 0.03$ to $8 \mathrm{mg} / \mathrm{mL}$ in $20 \mu \mathrm{L}$ ), or incubation with distillated water, were performed for $1 \mathrm{~h}$ at $37^{\circ} \mathrm{C}$. After blocking the wells with BSA $(0.03 \%)$, human washed platelets $\left(8 \times 10^{4} / \mu \mathrm{L}\right.$ in $\left.10 \mu \mathrm{L}\right)$ were added, followed by incubation for $1 \mathrm{~h}$ at $37^{\circ} \mathrm{C}$. Next, non-adherent platelets were removed, and adherent platelets were incubated with BCECF-AM $(4 \mu \mathrm{g} / \mathrm{mL}$ in $20 \mu \mathrm{L})$ for $30 \mathrm{~min}$ at $37^{\circ} \mathrm{C}$. Fluorescence intensity was measured using a plate reader (VictorX, PerkinElmer, Waltham, MA, USA). Values were compared with the control condition (non-coated plastic) by one-way ANOVA followed by Dunnett's post hoc test $\left(^{*} p<0.05,{ }^{* * *} p<0.001,{ }^{* * * *} p<0.000,1\right.$ values presented as SEM resulting from duplicate average of four independent experiments). Images were acquired using a fluorescence microscopy (Eclipse Ti2, Nikon) with a 20x objective. (B) $Z^{\prime}$-factor calculation to validate the platelet adhesion assay. In a 384-well microplate, $20 \mu \mathrm{L}$ of water were added to half of the microplate (176 wells-left side). In the other half, fibrinogen $(1 \mathrm{mg} / \mathrm{mL}$ ) diluted in water was added (176 wells-right side). After blocking the wells with BSA $(0.03 \%)$, human washed platelets $\left(8 \times 10^{4} / \mu \mathrm{L}\right.$ in $10 \mu \mathrm{L}$ ) were added, followed by incubation for $1 \mathrm{~h}$ at $37^{\circ} \mathrm{C}$. Next, non-adherent platelets were removed, and adherent platelets were incubated with BCECF-AM $(4 \mu \mathrm{g} / \mathrm{mL}$ in $20 \mu \mathrm{L})$ for $30 \mathrm{~min}$ at $37^{\circ} \mathrm{C}$. As a control, platelet adhesion on plastic was measured in the first and last columns. $\Delta$ represents delta: (Fibrinogen) - (non-coated). Fluorescence intensity (F.I.) was measured using a plate reader (VictorX, PerkinElmer, Waltham, MA, USA). The data of the graphs showing the $Z^{\prime}$-factor were calculated using the equation previously published by Zhang et al. [22].

\section{Discussion}

Adhesion to different substrates is an important step in physiological and pathological processes involving platelets. Events such as thrombosis depend on platelet adhesion to the exposed vessel ECM. Methods assessing platelet adhesion, allow the study of platelet's capacity to adhere to different ECM proteins, and also investigate adhesion inhibitors, pathophysiological processes as inflammation, immune-mediated host defense, and cancer metastasis. Several methods have been described and 
widely used, employing different platelet adhesion detection methods. In the present study, we selected two methods to further characterize and compare, employing either BCECF-AM or Calcein-AM. Our work, by standardizing the method, is relevant mainly in the contexts of scientific reproducibility and decision making, regarding the selection of submaximal concentrations of adhesion inhibitors.

The selected cell-permeable dyes to be investigated in the present work, BCECF-AM and Calcein-AM, were previously used with similar purposes and the original articles employing these methods were gathered in Tables 1 and 2, respectively. Although experiments employing SBB were also performed, our experiments hinted that this dye is not suitable to stain platelets, since it leads to platelet aggregation, when no substrate was added to the wells (non-coated conditions).

Both BCECF-AM and Calcein-AM are hydrophobic acetoxymethyl ester (AM) derivatives and they are both excited $(485 \mathrm{~nm})$ and emit $(530 \mathrm{~nm})$ at identic wavelengths [59]. The addiction of AM that makes them membrane permeable [60]. BCECF-AM structure derives from carboxyfluorescein, with two extra carboxylate groups [60] and is sensitive to $\mathrm{pH}$ [61], while Calcein is a polyanionic fluorescein derivative that bears six negative charges and two positive charges at $\mathrm{pH} 7$ [62] and is practically $\mathrm{pH}$-insensitive [61].

Calcein-AM and BCECF-AM are nonfluorescent in their native form and can be loaded into the cell as the charge-neutral, membrane-soluble form. Once in the cytosol, these probes are modified by nonspecific endogenous esterases upon cleavage of ester groups $[63,64]$. The cleaved probe is fluorescent and negatively charged, and for this reason less permeable to the plasma membrane, thereby being retained inside the cell [64]. Multicharged molecules such as BCECF and Calcein have typically cell retention times greater than $2 \mathrm{~h}$ at $37^{\circ} \mathrm{C}$ [64]. Generation of toxic photoproducts derived from $\mathrm{BCECF}$, as well as products of the deesterification reaction, namely, acetate and formaldehyde, have been previously reported [65]. Evidences also point Calcein-AM as being toxic to and pumped out of several cell lines [62]. On the other hand, studies showed that BCECF is not toxic under certain conditions, as for example in vitro fertilized mouse eggs [66] or brainstem cells [67]. One can argue that the toxicity observed is dependent on the dye concentration and on the cell type studied.

Tables 1 and 2 gather 13 and 25 studies performed over the years staining platelets with Calcein or BCECF, respectively. What is striking about these studies is the variability regarding the methodological settings. The tables highlight the following settings: type of plate; ECM protein, blocking agent (BSA) and dye concentrations; number of platelets and which type of measure was employed to detect the ECM-adherent platelets. Although not stated in all studies, the plates were acquired from varied companies. According to our observations, the ideal concentration of BSA for a successful inhibition of platelet adhesion depends on plate type used. The BSA titration studies revealed that all concentrations between $0.00075 \%$ and $4 \%$ BSA significantly reduced platelet adhesion to Invitrogen ${ }^{\mathrm{TM}}$ plates. Surprisingly, the same range of BSA concentrations failed to inhibit platelet adhesion to the surface of Greiner Bio-One (781186) one or Falcon (353072) plates, which were some of the plate brands used in studies of Tables 1 and 2. This could lead to a non-specific platelet adhesion.

The appropriate platelet concentration was also investigated, considering the feasibility of the test and the number of adherent platelets. A minimum of $4 \times 10^{4}$ platelets $/ \mu \mathrm{L}$ should be used, since no statistical difference was observed when a lower concentration of $2 \times 10^{4}$ platelets $/ \mu \mathrm{L}$ was used. A titration assay ranging from $4 \times 10^{4}$ to $1.6 \times 10^{6}$ platelets $/ \mu \mathrm{L}$ showed platelet adhesion linearity with a regression of 0.9971 and a concentration of $8 \times 10^{4}$ platelets $/ \mu \mathrm{L}$ was considered ideal for a reproducible assay, since it had a lower standard deviation, compared to higher concentrations, maintaining a measurable fluorescence signal. Furthermore, this number of platelets requires less blood, which also increases the feasibility of the assay for high-throughput screening. 
Table 1. Previous studies using Calcein-AM to measure platelet adhesion.

\begin{tabular}{|c|c|c|c|c|c|c|c|}
\hline Year & Type of Plate & ECM Concentration & Blocking BSA & Platelet Concentration & Dye Concentration & Type of Measurement & Ref. \\
\hline 2000 & $\begin{array}{l}\text { MicroFLUOR 96-well } \\
\text { (Dynatech) }\end{array}$ & $\begin{array}{c}\text { Collagen }(2 \mu \mathrm{g} / \text { well) or CRP (1.5 } \\
\mu \mathrm{g} / \text { well })\end{array}$ & $5 \%$ & N/A & $\begin{array}{l}\text { Pre-labeled platelets with } 2 \mu \mathrm{M} \\
\text { Calcein-AM at RT, } 30 \mathrm{~min}\end{array}$ & $\begin{array}{l}\text { Plate reader without lysing } \\
\text { platelets }\end{array}$ & [23] \\
\hline 2000 & $\begin{array}{l}\text { Microfluor 96-well } \\
\text { (Dynatech) }\end{array}$ & $\begin{array}{c}\text { Collagen ( } 2 \mu \mathrm{g} / \mathrm{well}) \text { or Convulxin } \\
(1.5 \mu \mathrm{g} / \mathrm{well})\end{array}$ & N/A & N/A & Pre-labeled platelets Calcein-AM & $\begin{array}{l}\text { Plate reader without lysing } \\
\text { platelets }\end{array}$ & [24] \\
\hline 2002 & $\begin{array}{l}\text { 96-well } \\
(\mathrm{N} / \mathrm{A})\end{array}$ & $\begin{array}{c}\text { Vitronectin } \\
(5 \mu \mathrm{g} / \mathrm{mL}) \text { or Fibrinogen }(10 \mu \mathrm{g} / \mathrm{mL})\end{array}$ & $3 \%$ & $100,000 / \mu \mathrm{L}$ & $\begin{array}{l}\text { Pre-labeled platelets with } 2.5 \mu \mathrm{M} \\
\text { Calcein-AM at RT, } 30 \mathrm{~min}\end{array}$ & $\begin{array}{l}\text { Plate reader after lysing } \\
\text { platelets }\end{array}$ & [25] \\
\hline 2003 & $\begin{array}{l}\text { Tissue culture 96-well } \\
\text { (Costar) }\end{array}$ & $\begin{array}{l}\text { D100 or D98 Fibrinogen fragments } \\
(20 \mu \mathrm{g} / \mathrm{mL})\end{array}$ & $1 \%$ & $100,000 / \mu \mathrm{L}$ & $\begin{array}{l}\text { Pre-labeled platelets with } 10 \mu \mathrm{M} \\
\text { Calcein-AM at } 37^{\circ} \mathrm{C}, 30 \mathrm{~min}\end{array}$ & $\begin{array}{l}\text { Plate reader without lysing } \\
\text { platelets }\end{array}$ & [26] \\
\hline 2004 & $\begin{array}{l}\text { MaxiSorp 96-well } \\
\text { (Invitrogen }{ }^{\mathrm{TM}} \text { ) }\end{array}$ & $\mathrm{N} / \mathrm{A}$ & $2 \%$ & $200,000 / \mu \mathrm{L}$ & $\begin{array}{l}\text { Pre-labeled platelets withn } 2 \mu \mathrm{M} \\
\text { Calcein-AM at } 37^{\circ} \mathrm{C}, 60 \mathrm{~min}\end{array}$ & Microscopy & [27] \\
\hline 2006 & $\begin{array}{l}\text { 96-well } \\
\text { (Greiner) }\end{array}$ & Fibronectin (5 $\mu \mathrm{g} /$ well) & N/A & $\mathrm{N} / \mathrm{A}$ & $\begin{array}{l}\text { Pre-labeled platelets with } 5 \mu \mathrm{M} \\
\text { Calcein-AM, } 60 \mathrm{~min}\end{array}$ & $\begin{array}{l}\text { Plate reader without lysing } \\
\text { platelets }\end{array}$ & [28] \\
\hline 2006 & $\begin{array}{l}\text { 96-well } \\
(\mathrm{N} / \mathrm{A})\end{array}$ & $\begin{array}{l}\text { Fibronectin }(5 \mu \mathrm{g} / \text { well) or } \\
\text { Collagen-III }(1 \mu \mathrm{g} / \text { well })\end{array}$ & N/A & $1000 / \mu \mathrm{L}$ & $\begin{array}{l}\text { Pre-labeled platelets with } 5 \mu \mathrm{M} \\
\text { Calcein-AM, } 60 \mathrm{~min}\end{array}$ & $\begin{array}{l}\text { Plate reader without lysing } \\
\text { platelets }\end{array}$ & [29] \\
\hline 2008 & $\begin{array}{l}\text { 384-well } \\
\text { (Corning no. 3711) }\end{array}$ & Fibrinogen $(50 \mu \mathrm{g} / \mathrm{mL})$ & $0.35 \%$ & $250,000 / \mu \mathrm{L}$ & $\begin{array}{l}\text { Pre-labeled platelets with } 7 \mu \mathrm{M} \\
\text { Calcein-AM at RT, } 30 \mathrm{~min}\end{array}$ & $\begin{array}{l}\text { Plate reader without lysing } \\
\text { platelets }\end{array}$ & [30] \\
\hline 2010 & $\begin{array}{l}\text { Immulon 4HBX 96-well } \\
\text { (ThermoLabsystems) }\end{array}$ & Fibrinogen ( 0.1 to $50 \mu \mathrm{g} / \mathrm{mL}$ ) & $1 \%$ & $100,000 / \mu \mathrm{L}$ & $\begin{array}{l}\text { Pre-labeled platelets with } 10 \mu \mathrm{M} \\
\text { Calcein-AM at } 37^{\circ} \mathrm{C}, 30 \mathrm{~min}\end{array}$ & $\begin{array}{c}\text { Plate reader without lysing } \\
\text { platelets }\end{array}$ & [31] \\
\hline 2010 & $\begin{array}{l}\text { Microfluor 96-well } \\
\text { (ThermoLabsystems) }\end{array}$ & Collagen $(2 \mu \mathrm{g} /$ well $)$ & $2 \%$ & $200,000 / \mu \mathrm{L}$ & $\begin{array}{l}\text { Pre-labeled platelets with } \\
\text { Calcein-AM }\end{array}$ & $\begin{array}{l}\text { Plate reader without lysing } \\
\text { platelets }\end{array}$ & [32] \\
\hline 2010 & $\begin{array}{l}\text { Immulon-2HB 96-well } \\
\text { (Dynex Technologies) }\end{array}$ & $\begin{array}{c}\text { Laminin-511 or Collagen (5 to } 200 \\
\mu \mathrm{g} / \mathrm{mL} \text { ) }\end{array}$ & $3 \%$ & $100,000 / \mu \mathrm{L}$ & $\begin{array}{l}\text { Pre-labeled platelets with } 4 \mu \mathrm{M} \\
\text { Calcein-AM }\end{array}$ & $\begin{array}{c}\text { Plate reader without lysing } \\
\text { platelets }\end{array}$ & [33] \\
\hline 2010 & $\begin{array}{l}\text { Microfluor 96-well } \\
\text { (ThermoLabsystems) }\end{array}$ & Fibrillar Collagen $(1 \mu \mathrm{g} /$ well $)$ & $2 \%$ & N/A & $\begin{array}{l}\text { Pre-labeled platelets with } 2 \mu \mathrm{M} \\
\text { Calcein-AM, } 30 \text { min }\end{array}$ & $\begin{array}{l}\text { Plate reader without lysing } \\
\text { platelets }\end{array}$ & [34] \\
\hline 2011 & $\begin{array}{l}\text { Microfluor } 2 \text { high-affinity 96-well } \\
\text { (Thermo Electron Co) }\end{array}$ & $\begin{array}{l}\text { Fibronectin }(1 \mu \mathrm{g} / \mathrm{mL}), \text { Fibrinogen } \\
(100 \mu \mathrm{g} / \mathrm{mL}) \text { or Collagen-I }(2 \mu \mathrm{g} / \mathrm{mL})\end{array}$ & $2 \%$ & $200,000 / \mu \mathrm{L}$ & $\begin{array}{l}\text { Pre-labeled platelets with } 2 \mu \mathrm{M} \\
\text { Calcein-AM at RT, } 30 \mathrm{~min}\end{array}$ & $\begin{array}{l}\text { Plate reader without lysing } \\
\text { platelets }\end{array}$ & [35] \\
\hline 2011 & $\begin{array}{l}\text { 96-well } \\
\text { (N/A) }\end{array}$ & $\begin{array}{l}\text { Fibrinogen (concentration not } \\
\text { mentioned) }\end{array}$ & $0.35 \%$ & $200 / \mu \mathrm{L}$ & $\begin{array}{l}\text { Pre-labeled platelets with } 7 \mu \mathrm{M} \\
\text { Calcein-AM }\end{array}$ & $\begin{array}{l}\text { Plate reader without lysing } \\
\text { platelets }\end{array}$ & [36] \\
\hline 2011 & $\begin{array}{l}\text { Polystyrene 96-well } \\
\text { (Nunc) }\end{array}$ & Fibrinogen $(10 \mu \mathrm{g} / \mathrm{mL})$ & N/A & $200,000 / \mu \mathrm{L}$ & $\begin{array}{l}\text { Pre-labeled platelets with } 7 \mu \mathrm{M} \\
\text { Calcein-AM at } 37^{\circ} \mathrm{C}, 30 \mathrm{~min}\end{array}$ & $\begin{array}{l}\text { Plate reader without lysing } \\
\text { platelets }\end{array}$ & [37] \\
\hline 2012 & $\begin{array}{l}\text { Microfluor 96-well } \\
\text { (ThermoLabsystems) }\end{array}$ & Collagen $(1 \mu \mathrm{g} /$ well $)$ & $2 \%$ & $200,000 / \mu \mathrm{L}$ & $\begin{array}{l}\text { Pre-labeled platelets with } 2 \mu \mathrm{M} \\
\text { Calcein-AM at RT, } 30 \mathrm{~min}\end{array}$ & $\begin{array}{l}\text { Plate reader without lysing } \\
\text { platelets }\end{array}$ & [38] \\
\hline 2012 & $\begin{array}{l}\text { 96-well } \\
\text { (N/A) }\end{array}$ & Fibrinogen $(50 \mu \mathrm{g} / \mathrm{mL})$ & $1 \%$ & $200,000 / \mu \mathrm{L}$ & $\begin{array}{l}\text { Pre-labeled platelets with } 2.5 \mu \mathrm{M} \\
\text { Calcein-AM at RT, } 15 \text { min }\end{array}$ & $\begin{array}{l}\text { Plate reader without lysing } \\
\text { platelets }\end{array}$ & [39] \\
\hline 2013 & $\begin{array}{c}\text { 96-well } \\
(\mathrm{N} / \mathrm{A})\end{array}$ & Collagen $(40 \mu \mathrm{g} / \mathrm{mL})$ & $5 \%$ & N/A & $\begin{array}{l}\text { Pre-labeled platelets with } 2.5 \mu \mathrm{M} \\
\text { Calcein-AM at RT, } 15 \mathrm{~min}\end{array}$ & $\begin{array}{c}\text { Plate reader after lysing } \\
\text { platelets }\end{array}$ & [40] \\
\hline 2013 & $\begin{array}{l}\text { Microfluor 96-well plates } \\
\text { (ThermoLabsystems) }\end{array}$ & Collagen-I $(20 \mu \mathrm{g} / \mathrm{mL})$ & $2 \%$ & $200,000 / \mu \mathrm{L}$ & $\begin{array}{l}\text { Pre-labeled platelets with } 2 \mu \mathrm{M} \\
\quad \text { Calcein-AM at RT, } 30 \mathrm{~min}\end{array}$ & $\begin{array}{l}\text { Plate reader without lysing } \\
\text { platelets }\end{array}$ & [41] \\
\hline 2014 & $\begin{array}{l}\text { Tissue culture 96-well } \\
\text { (Costa) }\end{array}$ & Fragment D98 $(10 \mu \mathrm{g} / \mathrm{mL})$ & $1 \%$ & $100,000 / \mu \mathrm{L}$ & $\begin{array}{l}\text { Pre-labeled platelets with } 10 \mu \mathrm{M} \\
\text { Calcein-AM at } 37^{\circ} \mathrm{C}, 30 \mathrm{~min}\end{array}$ & $\begin{array}{l}\text { Plate reader without lysing } \\
\text { platelets }\end{array}$ & [42] \\
\hline
\end{tabular}


Table 1. Cont

\begin{tabular}{|c|c|c|c|c|c|c|c|}
\hline Year & Type of Plate & ECM Concentration & Blocking BSA & Platelet Concentration & Dye Concentration & Type of Measurement & Ref. \\
\hline 2015 & $\begin{array}{l}\text { Microfluor 96-well } \\
\text { (Thermo Labsystems) }\end{array}$ & 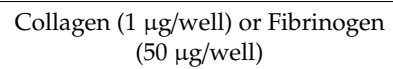 & $2 \%$ & $200,000 / \mu \mathrm{L}$ & $\begin{array}{l}\text { Pre-labeled platelets with } 2 \mu \mathrm{M} \\
\text { Calcein-AM at RT, } 30 \text { min }\end{array}$ & $\begin{array}{c}\text { Plate reader without lysing } \\
\text { platelets }\end{array}$ & [43] \\
\hline 2016 & $\begin{array}{l}\text { 96-well } \\
\text { (N/A) }\end{array}$ & Fibrinogen $(50 \mu \mathrm{g} / \mathrm{mL})$ & $5 \%$ & 500,000/well & $\begin{array}{l}\text { Pre-labeled platelets with } 7 \mu \mathrm{M} \\
\text { Calcein-AM }\end{array}$ & $\begin{array}{l}\text { Plate reader without lysing } \\
\text { platelets }\end{array}$ & [44] \\
\hline 2016 & $\begin{array}{c}\text { 96-well } \\
\text { (Corning) }\end{array}$ & Collagen $(100 \mu \mathrm{g} / \mathrm{mL})$ & $1 \%$ & N/A & $\begin{array}{l}\text { Pre-labeled platelets with } 10 \\
\text { ng/mL Calcein for 30min } 37 \mathrm{C}\end{array}$ & $\begin{array}{l}\text { Plate reader without lysing } \\
\text { platelets }\end{array}$ & [45] \\
\hline 2017 & $\begin{array}{l}\text { 96-well } \\
\text { (Greiner Bio-one, 655096) }\end{array}$ & $\begin{array}{l}\text { Fibrinogen or Fibrinogen fragment } \\
\text { D98 }(10 \mu \mathrm{g} / \mathrm{mL})\end{array}$ & $0.35 \%$ & $200,000 / \mu \mathrm{L}$ & $\begin{array}{l}\text { Pre-labeled platelets with } 7 \mathrm{uM} \\
\text { Calcein for 30min RT }\end{array}$ & $\begin{array}{l}\text { Plate reader without lysing } \\
\text { platelets }\end{array}$ & [46] \\
\hline 2020 & $\begin{array}{l}\text { 96-well } \\
\text { (N/A) }\end{array}$ & Collagen $(20 \mu \mathrm{g} / \mathrm{mL})$ & $2 \%$ & $200,000 / \mu \mathrm{L}$ & $\begin{array}{l}\text { Pre-labeled platelets with } 4 \mu \mathrm{M} \\
\text { Calcein-AM at } 37^{\circ} \mathrm{C}, 60 \mathrm{~min}\end{array}$ & $\begin{array}{c}\text { Plate reader without lysing } \\
\text { platelets }\end{array}$ & [47] \\
\hline
\end{tabular}

Table 2. Previous studies using BCECF-AM to measure platelet adhesion.

\begin{tabular}{|c|c|c|c|c|c|c|c|}
\hline Year & Type of Plate & ECM Concentration & Blocking BSA & Platelet Concentration & Dye Concentration & Type of Measurement & Ref. \\
\hline 1996 & $\begin{array}{l}\text { 96-well } \\
\text { (N/A) }\end{array}$ & Collagen $(100 \mu \mathrm{g} / \mathrm{mL})$ & $0.35 \%$ & $300,000 / \mu \mathrm{L}$ & $\begin{array}{l}\text { Pre-labeled platelets with } 2 \mu \mathrm{M} \\
\text { BCECF-AM at } 37^{\circ} \mathrm{C}, 30 \mathrm{~min}\end{array}$ & $\begin{array}{l}\text { Plate reader without lysing } \\
\text { platelets }\end{array}$ & [48] \\
\hline 1997 & $\begin{array}{l}\text { 96-well } \\
\text { (Falcon) }\end{array}$ & $\begin{array}{l}\text { Collagen-I or Fibrinogen } \\
\qquad(100 \mu \mathrm{g} / \mathrm{mL})\end{array}$ & $0.0005 \%$ & $375,000 / \mu \mathrm{L}$ & $\begin{array}{l}\text { Pre-labeled platelets with } 6 \mathrm{mM} \\
\text { BCECF-AM at } 37^{\circ} \mathrm{C}, 30 \mathrm{~min}\end{array}$ & $\begin{array}{l}\text { Plate reader after lysing } \\
\text { platelets }\end{array}$ & [49] \\
\hline 1997 & $\begin{array}{l}\text { 96-well } \\
\text { (Costar) }\end{array}$ & $\begin{array}{l}\text { Fibronectin or Vitronectin (0.05 to } \\
1.5 \mu \mathrm{g} / \text { well) }\end{array}$ & $0.50 \%$ & $300,000 / \mu \mathrm{L}$ & $\begin{array}{l}\text { Pre-labeled platelets with } 5 \mu \mathrm{M} \\
\text { BCECF-AM at } 37^{\circ} \mathrm{C}, 40 \mathrm{~min}\end{array}$ & $\begin{array}{l}\text { Plate reader without lysing } \\
\text { platelets }\end{array}$ & [50] \\
\hline 1997 & $\begin{array}{l}\text { 96-well } \\
\text { (Costar) }\end{array}$ & $\begin{array}{c}\text { Fibronectin, Vitronectin, vWF, } \\
\text { laminin }(1 \mu \mathrm{g} / \text { well }) \text { or collagen-IV } \\
(5 \mu \mathrm{g} / \text { well })\end{array}$ & $0.50 \%$ & $300,000 / \mu \mathrm{L}$ & $\begin{array}{l}\text { Pre-labeled platelets with } 5 \mu \mathrm{M} \\
\text { BCECF-AM at } 37^{\circ} \mathrm{C}, 40 \mathrm{~min}\end{array}$ & $\begin{array}{l}\text { Plate reader without lysing } \\
\text { platelets }\end{array}$ & [51] \\
\hline 1998 & $\begin{array}{l}\text { 96-well } \\
\text { (N/A) }\end{array}$ & Fibrinogen (0.01, 0.1 and $2 \mu \mathrm{g} /$ well $)$ & N/A & $400,000 / \mu \mathrm{L}$ & $\begin{array}{l}\text { Pre-labeled platelets with } 12 \mu \mathrm{M} \\
\text { BCECF-AM at } 37^{\circ} \mathrm{C}, 30 \mathrm{~min}\end{array}$ & $\begin{array}{c}\text { Plate reader without lysing } \\
\text { platelets }\end{array}$ & [52] \\
\hline 1999 & $\begin{array}{l}\text { 96-well } \\
\text { (Immulon-2) }\end{array}$ & Fibrinogen ( $1 \mathrm{ng}$ to $2 \mu \mathrm{g} /$ well) & N/A & $4,000,000 / \mu \mathrm{L}$ & $\begin{array}{l}\text { Pre-labeled platelets with } 6 \mu \mathrm{M} \\
\text { BCECF-AM at } 37^{\circ} \mathrm{C}, 30 \mathrm{~min}\end{array}$ & $\begin{array}{l}\text { Plate reader without lysing } \\
\text { platelets }\end{array}$ & [53] \\
\hline 1999 & $\begin{array}{l}\text { 96-well } \\
\text { (Costar) }\end{array}$ & $\begin{array}{l}\text { Fibronectin, Vitronectin, vWF or } \\
\text { Laminin }(120 \mu \mathrm{g} / \mathrm{mL})\end{array}$ & $0.50 \%$ & $300,000 / \mu \mathrm{L}$ & $\begin{array}{l}\text { Pre-labeled platelets with } 5 \mu \mathrm{M} \\
\text { BCECF-AM at } 37^{\circ} \mathrm{C}, 40 \mathrm{~min}\end{array}$ & $\begin{array}{l}\text { Plate reader without lysing } \\
\text { platelets }\end{array}$ & [54] \\
\hline 2008 & $\begin{array}{l}\text { 96-well } \\
\text { (N/A) }\end{array}$ & $\begin{array}{l}\text { Collagen or Fibrinogen } \\
\qquad(50 \mu \mathrm{g} / \mathrm{mL})\end{array}$ & $1 \%$ & N/A & $\begin{array}{l}\text { Pre-labeled platelets with } \\
\text { BCECF-AM for } 40 \text { min (temperature } \\
\text { and concentration N/A) }\end{array}$ & Microscopy & [55] \\
\hline 2010 & $\begin{array}{l}\text { 96-well } \\
\text { (N/A) }\end{array}$ & Collagen or Fibrinogen $(50$ g/mL) & $1 \%$ & N/A & $\begin{array}{l}\text { Pre-labeled platelets with } \\
\text { BCECF-AM for } 30 \text { min (temperature } \\
\text { and concentration N/A) }\end{array}$ & $\begin{array}{l}\text { Plate reader without lysing } \\
\text { platelets }\end{array}$ & [56] \\
\hline 2018 & $\begin{array}{l}\text { 96-well } \\
(\mathrm{N} / \mathrm{A})\end{array}$ & Collagen $(10 \mu \mathrm{g} / \mathrm{mL})$ & $0.5 \%$ or $0.05 \%$ & N/A & $\begin{array}{l}\text { Pos-labelling platelets with } 12 \mu \mathrm{M} \\
\text { BCECF-AM (incubation time and } \\
\text { temperature N/A) }\end{array}$ & $\begin{array}{l}\text { Plate reader after lysing } \\
\text { platelets }\end{array}$ & [57] \\
\hline 2019 & $\begin{array}{l}\text { 96-well } \\
\text { (N/A) }\end{array}$ & $\begin{array}{l}\text { Fibrinogen } \\
(100 \mu \mathrm{g} / \mathrm{mL})\end{array}$ & $5 \%$ & $200,000 / \mu \mathrm{L}$ & $\begin{array}{l}\text { Pre-labeled platelets with } \\
\text { BCECF-AM at } 37^{\circ} \mathrm{C} \text { for } 30 \text { min } \\
\text { (concentration N/A) }\end{array}$ & $\begin{array}{l}\text { Plate reader after lysing } \\
\text { platelets }\end{array}$ & [58] \\
\hline
\end{tabular}


Different ECM proteins constitute substrates for platelets adhesion, being collagen, fibrinogen, fibronectin, vitronectin, $\mathrm{vWF}$, and laminin some of the proteins used in previous adhesion studies (Tables 1 and 2). In our experiment, we tested a panel of different ECM protein coatings, and titrated the best concentration for that particular protein, by platelet staining with BCECF. Interestingly, substrates such as fibrinogen presented the highest number of adherent platelets, reaching the maximal adhesion at $2 \mathrm{mg} / \mathrm{mL}$, being the plasmatic concentration of this protein between $2-4 \mathrm{mg} / \mathrm{mL}$ [68], which is an important factor for platelet activation. The same seems to happen in the context of adhesion. However, most of the previous assays employed fibrinogen in a concentration ranging $50-100 \mu \mathrm{g} / \mathrm{mL}$, which might not be the concentration leading to the maximal platelet adhesion. This supports the need of a standardized protocol to measure platelet adhesion. On the other hand, the least adhesive substrate seems to be vitronectin, which failed to induce significant platelet adhesion in our study. The adhesion to collagen type III did not reach statistical differences, although an increased adhesion tendency could be observed. Regarding one of the most commonly used protein to study platelets adhesion, collagen-I, in low concentrations, as used in some of the studies, failed to trigger platelet adhesion in a statistically significant manner, which was only reached with concentrations of $2-8 \mu \mathrm{g} / \mathrm{mL}$ or $64 \mu \mathrm{g} / \mathrm{mL}$ for non-fibrilar or fibrilar collagen I, respectively. Interestingly, laminins-411 and -511 at concentrations ranging $7.5-15 \mu \mathrm{g} / \mathrm{mL}$, and 10 and $15 \mu \mathrm{g} / \mathrm{mL}$, respectively, are also more potent substrates for platelet adhesion, compared to other tested substrates. Altogether, the discrepancies in the concentration range of ECM protein coatings between studies reinforce the need for standardized protocols, as here proposed, which contributes for the reproducibility of results. Most importantly, our experiments in which adherent platelets to collagen-I were stained with either BCECF-AM or Calcein-AM, highlighted that BECF-AM, although it presented higher standard deviation values, did reach statically significant differences. Using BCECF-AM, the number of adherent platelets detected was much higher than when platelets were pre-stained with Calcein-AM. Calcein-AM staining of platelets failed to reach significant detectable differences between platelets adhesion to collagen-I coated or non-coated surfaces.

Regarding the dye fluorescence detection method employed can be either by analyzing the cells under a fluorescence microscope or by quantitatively measuring the fluorescence, using a fluorescence plate reader. An advantage of this assay is that both analysis can be performed. The fluorescence measure using a plate reader assures that the quantitative analysis of the fluorescence-based assay is reliable. Furthermore, our studies demonstrate that microscopic analysis can be posteriorly performed, allowing the analysis not only the fluorescence but also the cell morphology, and understand if platelets spread more or less in a given substrate. Importantly, in order to avoid photo bleaching, microscopy should be performed after the fluorescence quantitative measurement in the plate reader. To further test the method's sensitivity, a collagen-I adhesion inhibitor, which blocks the integrin $\alpha 2 \beta 1$, successfully decreased the adhesion of platelets, which was detected by BCECF-AM staining.

Lastly, and in order to validate the assay quality, the $Z^{\prime}$-factor was calculated. An optimal $Z^{\prime}$-factor value (higher than 0.5 ) was attained employing the following experimental settings: Plate coated with $1 \mathrm{mg} / \mathrm{mL}$ of fibrinogen, as it led to maximal platelet adhesion; blocking agent BSA in a concentration of $0.03 \%$; platelets in a concentration of $8 \times 10^{4} / \mu \mathrm{L}$ in $10 \mu \mathrm{L}$ incubated for $1 \mathrm{~h}$ at $37^{\circ} \mathrm{C}$, and stained with $4 \mu \mathrm{g} / \mathrm{mL}$ BCECF-AM in $20 \mu \mathrm{L}$ for $30 \mathrm{~min}$ at $37^{\circ} \mathrm{C}$. This analysis is important, as it states the robustness of the assay, which might contribute for a more reproducible assay. This is an essential aspect, as reproducibility is a major problem in science. In addition, the Z-Factor value assures the compatibility of the assay with a high-throughput screening format.

The present assay is performed in a 2D setting; however, in an updated version of the assay, 3D matrix gels could be potentially applied to assess platelet adhesion under near-physiological conditions. The current available technology does not allow the evaluation of platelet adhesion under shear stress conditions in a high-throughput screening format, which constitutes a limitation to the study. Therefore, this assay cannot be applied to study shear-stress dependent receptors, such as GPIb and its interaction with vWF. 


\section{Materials and Methods}

\subsection{Materials}

The following microplates were used in this study: Nunc MaxiSorp ${ }^{\text {TM }}$ 96-well clear flat-bottom (44-2404-21, Invitrogen ${ }^{\mathrm{TM}}$, Carlsbad, CA, USA), Falcon ${ }^{\circledR}$ 96-well clear flat-bottom tissue culture (TC)-treated (Corning, 353072, Corning, NY, USA), Greiner Bio-One 96-well clear flat-bottom (Greiner Bio-One, 655180, Kremsmünster, Austria) and Greiner Bio-One 384-well clear flat-bottom (Greiner Bio-One, 781186). Prostaglandin E1 (Sigma, P7527, St. Louis, MO, USA) was used for washed platelet preparation. Microplate wells were coated with the following ECM proteins: Fibrinogen (Sigma, F8630), fibronectin (Sigma, F4759), non-fibrillar collagen type-I (Sigma, C7661), fibrillar collagen type-I (möLab, 0203009, Langenfeld, Germany), collagen type-III (Sigma, C4407), collagen type-IV (Sigma, C7521), laminin-411 (BioLamina, LN411-02, Sundbyberg, Sweden), laminin-511 (BioLamina, LN511-02), and vitronectin (Sigma, 5051). Collagen-related peptide (CRP), also used for coating, was purchased from University of Cambridge. BSA (Sigma, A7906) was used to block the non-specific binding to the wells. The following dyes were used to detect platelet adhesion: BCECF-AM (Sigma, B8806), Calcein-AM (Sigma, 17783) and Sudan Black B (Sigma, 199664). TC-I 15, an $\alpha 2 \beta 1$ integrin inhibitor was obtained from R\&D Systems (4527, Minneapolis, MN, USA). The following equipment was used in this study: Plate reader (PerkinElmer, Victor X3) and microscope (Nikon Eclipse Ti2).

\subsection{Washed Platelet Preparation}

Washed platelets were prepared as previously described [57]. Human blood was collected from healthy volunteers, who had not been medicated in the previous 10 days, using a $10 \mathrm{~mL}$ tube (SARSTEDT, S-Monovette, Nümbrecht, Germany), maintaining a 6:1 ratio of whole blood to ACD (117 $\mathrm{mM}$ sodium citrate, $78 \mathrm{mM}$ citric acid and $282 \mathrm{mM}$ dextrose). Platelet-rich plasma (PRP) was obtained by two centrifugation steps at $500 \times g$ for $15 \mathrm{~min}$ at room temperature. Aliquots of PRP $(1 \mathrm{~mL})$ were distributed in $2 \mathrm{~mL}$ centrifuge tubes containing $22.5 \mu \mathrm{M}$ prostaglandin E1 (PGE1) and centrifuged at $10,000 \times \mathrm{g}$ for $30 \mathrm{~s}$. The platelet pellet was resuspended in magnesium- and calcium-free tyrode buffer at pH 6.2 $\left(17 \mu \mathrm{M}\right.$ PGE1, $137 \mathrm{mM} \mathrm{NaCl}, 2.7 \mathrm{mM} \mathrm{KCl}, 3 \mathrm{mM} \mathrm{NaH} \mathrm{PO}_{4}, 10 \mathrm{mM}$ hepes, $1.25 \mathrm{mM}$ $\mathrm{NaHCO}_{3}$, and $5.6 \mathrm{mM}$ dextrose), and this procedure was repeated once more. Finally, platelets were resuspended in tyrode buffer, $\mathrm{pH} 7.4$, in absence of PGE1 but containing $2 \mathrm{mM} \mathrm{CaCl} 2$ and $1 \mathrm{mM}$ $\mathrm{MgCl}_{2}$. All participants provided informed consent in accordance with the Helsinki Declaration and all protocols were approved by the Swiss ethics committee (project-ID 2017-00732, date of approval 23.05.2017, Commission cantonale d'éthique de la recherche sur l'être humain).

\subsection{Study Design}

\subsubsection{6-Well Plate and BCECF-AM}

ECM proteins were added to a 96-well plate in different concentrations ( $50 \mu \mathrm{L} /$ well) followed by incubation for $1 \mathrm{~h}$ at $37^{\circ} \mathrm{C}$. The plate content was discarded, and the wells were washed 3 times with distillated water $(100 \mu \mathrm{L} /$ well $)$. Next, different concentrations of BSA were added to the well to block non-specific binding of platelets. After $1 \mathrm{~h}$ incubation at $37^{\circ} \mathrm{C}$, the wells coated with ECM proteins and blocked with BSA were washed 3 times with distilled water $(100 \mu \mathrm{L} /$ well $)$. Immediately after, $50 \mu \mathrm{L}$ of different concentration of platelets were added and incubated for $1 \mathrm{~h}$ at $37^{\circ} \mathrm{C}$. Non-bond platelets were washed with tyrode buffer, pH $7.4(100 \mu \mathrm{L} /$ well $)$, and adherent platelets were stained with different concentrations of BCECF-AM diluted in tyrode buffer, pH $7.4(50 \mu \mathrm{L} /$ well), for $30 \mathrm{~min}$ at $37^{\circ} \mathrm{C}$. Next, the BCECF-AM excess was removed by washing the plate 3 times with tyrode buffer, pH $7.4(100 \mu \mathrm{L} /$ well). Fluorescent signal of BCECF-AM was measured using a plate reader (VictorX, PerkinElmer) with the parameters shown in Table 3. Fluorescent signal of BCECF-AM was also measured after lysing adhered platelets. For that, lysis buffer $(0.1 \%$ SDS in $30 \mathrm{mM}$ Tris $\mathrm{pH} 8.8)$ was added after washing the excess of BCECF-AM. For microscopy purposes, images from non-lysed 
platelets were acquired using a fluorescence microscope. Figure 7 schematically represents the study design using BCECF-AM.

Table 3. Plate reader parameters for BCECF-AM and Calcein-AM.

\begin{tabular}{cc}
\hline Dye & BCECF-AM and Calcein-AM \\
\hline Signal & Fluorescence \\
\hline Excitation: & $485 \mathrm{~nm}$ \\
\hline Emission: & $535 \mathrm{~nm}$ \\
\hline Measurement time: & $0.1 \mathrm{~s}$ \\
\hline Lamp energy (CW): & 15000 \\
\hline Emission side: & Above \\
\hline Temperature: & $22{ }^{\circ} \mathrm{C}$ \\
\hline
\end{tabular}

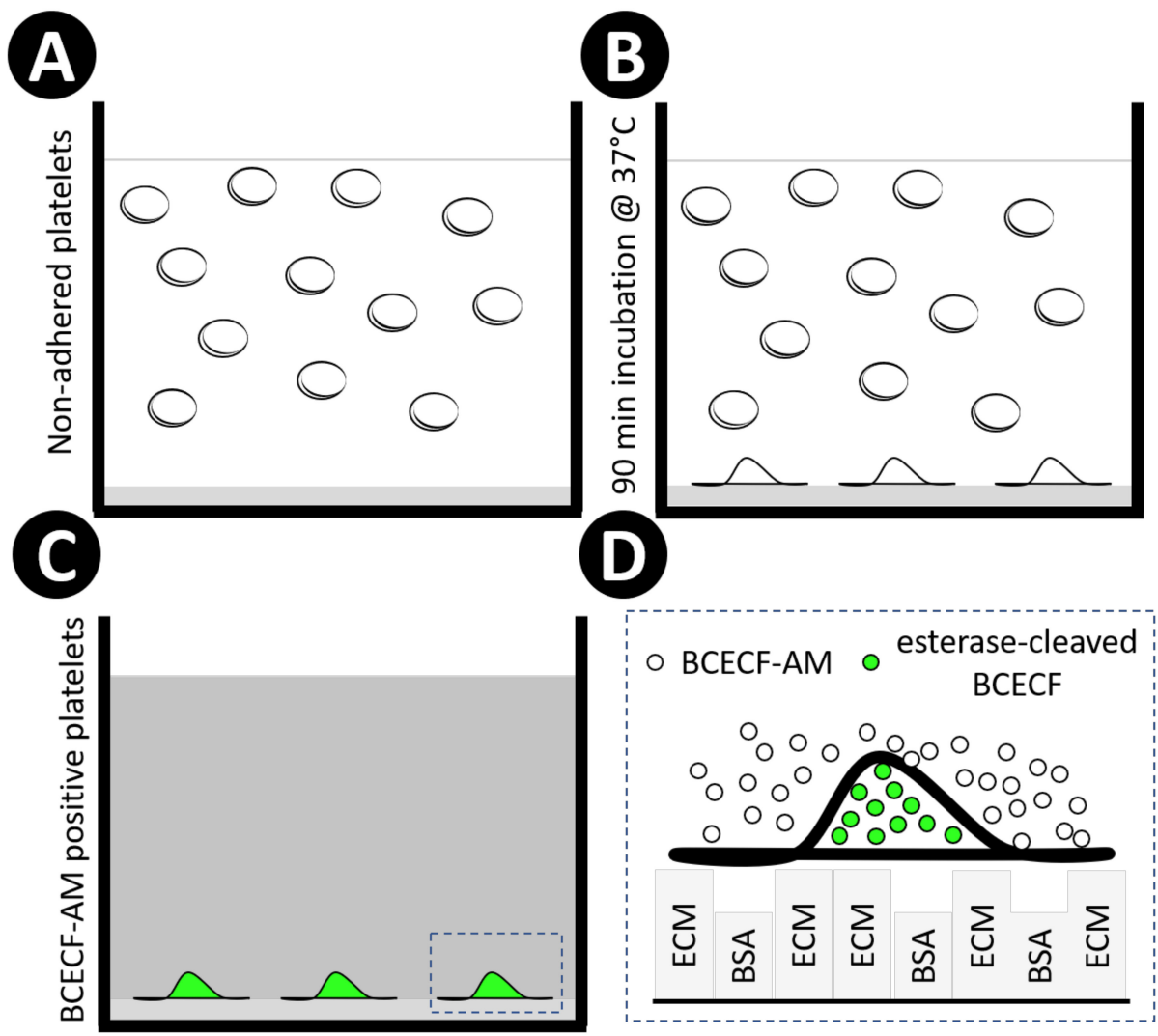

ECM-coated surface blocked with BSA

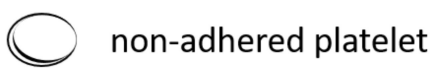

$\frown$ adhered platelet

Figure 7. Schematic representation of the study design using BCECF-AM. Extracellular matrix proteins were employed to coat 96- or 384-well microplates, followed by BSA blocking, both incubated for $1 \mathrm{~h}$ at $37^{\circ} \mathrm{C}$. Next, human washed platelets were added into wells (A). and incubated for $90 \mathrm{~min}$ at $37^{\circ} \mathrm{C}(\mathbf{B})$. Non-adherent platelets were washed away with tyrode buffer, and adherent platelets were incubated with diluted BCECF-AM for $30 \mathrm{~min}$ at $37^{\circ} \mathrm{C}$. The excess of BCECF-AM was removed by washing the plate 3 times with tyrode buffer (C). Non-fluorescent BCECF-AM is permeable to the platelet membrane. Once inside the platelet, intracellular esterases cleave the ester bond, releasing BCECF, which is the fluorescent form of the molecule. In addition, the cleavage of lipophilic blocking groups by esterases, leads to a charged form of BCECF, which leaks out of cells more slowly than BCECF-AM [69]. Rectangular boxes represent ECM and BSA coating (D). 


\subsubsection{6-Well Plate and Calcein-AM}

For the experiment using Calcein-AM, platelets were pre-stained following the protocol previous published by several authors (see Table 1). Briefly, PRP obtained by centrifugation of the whole blood was incubated with Calcein-AM $(2 \mu \mathrm{g} / \mathrm{mL})$ for $1 \mathrm{~h}$ at $37^{\circ} \mathrm{C}$. Next, washed stained-platelets were obtained after a series of washing steps as described in the Section 4.2. Adhesion of pre-stained platelets was measured as the platelets stained with BCECF-AM in a 96-well plate. Fluorescence signal of Calcein-AM was measured using a plate reader with the parameters shown in Table 3. Fluorescent signal of Calcein-AM was also measured after lysing adherent platelets. For that, lysis buffer $(0.1 \%$ SDS in $30 \mathrm{mM}$ Tris $\mathrm{pH} 8.8$ ) was added to adherent platelets.

\subsubsection{4-Well Plate and BCECF-AM}

Fibrinogen was added to a 384 -well plate in different concentrations $(0.03$ to $8 \mathrm{mg} / \mathrm{mL}-20 \mu \mathrm{L} / \mathrm{well})$, followed by incubation for $1 \mathrm{~h}$ at $37^{\circ} \mathrm{C}$. The content of the plate was discarded, and the wells were washed 3 times with distilled water $(20 \mu \mathrm{L} /$ well). Next, BSA $0.03 \%$ was added to the wells to block non-specific binding of platelets. After $1 \mathrm{~h}$ incubation at $37^{\circ} \mathrm{C}$, the wells coated with fibrinogen and blocked with BSA were washed 3 times with distilled water $(20 \mu \mathrm{L} /$ well). Immediately after, platelets $\left(8 \times 10^{4} / \mu \mathrm{L}\right.$ in $\left.10 \mu \mathrm{L}\right)$ were added and incubated for $1 \mathrm{~h}$ at $37^{\circ} \mathrm{C}$. Non-adherent platelets were washed away with tyrode buffer, pH 7.4 $(20 \mu \mathrm{L} /$ well $)$, and adhered platelets were incubated with BCECF-AM diluted in tyrode buffer, pH $7.4(4 \mu \mathrm{g} / \mathrm{mL}, 20 \mu \mathrm{L} /$ well $)$, for $30 \mathrm{~min}$ at $37^{\circ} \mathrm{C}$. Next, the excess of BCECF-AM was washed 3 times with tyrode buffer, pH 7.4 $(20 \mu \mathrm{L} /$ well). BCECF-AM fluorescence signal was measured using a plate reader with the parameters as shown in Table 3. For microscopy purposes, images from non-lysed platelets were acquired using a fluorescent microscope.

\subsection{Data Analysis}

To validate the assay, fibrinogen $(1 \mathrm{mg} / \mathrm{mL})$ was added to half of the 384-well microplate (176 wells—right side). In the other half, water was added (176 wells-left side). As a control, platelet adhesion on plastic was measured in the first and last columns. The following formula was used to calculate the $Z^{\prime}$-factor value, as described in a previous publication [22].

$$
Z^{\prime} \text { factor }=1-\frac{3 S D \text { of max response }+3 \mathrm{SD} \text { of } \min \text { response }}{\text { mean of max response }- \text { mean of min response }}
$$

Unless otherwise stated, triplicates were performed in every experiment using platelets from four different donors. The data are expressed as mean \pm standard error of mean (SEM). Each measurement represents the average of two wells within the same condition. Statistical differences among groups were analyzed by one-way analysis of variance (ANOVA) followed by Dunnett's test. T-test was used to determine whether there was a difference in collagen-coated and non-coated wells for assay linearity of platelet adhesion in a 96-well plate. Two-way ANOVA followed by Tukey's post hoc test was used to determine the difference between BCECF-AM and Calcein-AM techniques. Probability value $(p)<0.05$ was considered statistically significant. GraphPad Prism 6.0 (San Diego, CA, USA) was used to perform the statistical analysis.

\section{Conclusions}

Our studies importantly highlight the potential advantages and disadvantages of different methodological approaches to detect platelet adhesion by measuring fluorescent dyes. As an essential step of the thrombus formation process, platelet adhesion can be studied in vitro. An advantage of the proposed in vitro assay is its versatility, as different ECM proteins representative of the ECM of the healthy or injured vessel can be studied, and their individual effect on platelet adhesion pin-pointed. Furthermore, drug discovery to identify new adhesion inhibitors can also be performed, and murine, human platelets or platelets from patients with platelet-related pathologies can be studied for their 
adhesive capacities. Lastly, the development of a high-throughput assay, which is both fast and inexpensive, is of extreme interest for drug development. The standardization of a methodological approach that can fulfill all these criteria, and that can be employed by both researchers, drug developers and clinicians, to analyze platelet adhesion in a reproducible and comparable way, is essential. In the present work, we optimized and standardized a high-throughput method able to measure quantitatively platelet adhesion to different substrates, allowing also morphological characterization of the adherent platelets. The methodological approach is detailed in the standard operating procedure (SOP) present in the supplemental material.

Supplementary Materials: Supplementary Materials can be found at http:/www.mdpi.com/1422-0067/21/18/6539/s1.

Author Contributions: Conceptualization, A.M.L. and N.S.; methodology, A.M.L.; validation, D.S.S.A., F.C., T.L. and C.M.E.K.; formal analysis, A.M.L., A.C.M.C. and R.A.F.-S.; investigation, D.S.S.A., F.C., T.L. and C.M.E.K.; writing-Original draft preparation, A.M.L., A.C.M.C. and R.A.F.-S.; writing-Review and editing, A.M.L., A.C.M.C. and R.A.F.-S.; visualization, A.M.L.; supervision, A.M.L. and N.S.; project administration, A.M.L.; funding acquisition, A.M.L. and N.S.; All authors have read and agreed to the published version of the manuscript.

Funding: This work was supported by the Novartis Foundation for medical-biological Research.

Acknowledgments: We thank Point santé and Discovery Learning Labs from EPFL for the technical support.

Conflicts of Interest: The authors declare no conflict of interest. The funders had no role in the design of the study; in the collection, analyses, or interpretation of data; in the writing of the manuscript, or in the decision to publish the results.

$\begin{array}{ll}\text { Abbreviations } \\ \text { AM } & \text { Acetoxymethyl } \\ \text { BCECF } & 2^{\prime}, 7^{\prime} \text {-Bis-(2-Carboxyethyl)-5-(and-6)-Carboxyfluorescein } \\ \text { BSA } & \text { Bovine Serum Albumin } \\ \text { CRP } & \text { Collagen-Related Peptide } \\ \text { ECM } & \text { Extracellular Matrix } \\ \text { Fbg } & \text { Fibrinogen } \\ \text { N/A } & \text { Not Available } \\ p & \text { Probability value } \\ \text { PGE1 } & \text { Prostaglandin E1 } \\ \text { RT } & \text { Room Temperature } \\ \text { PRP } & \text { Platelet-Rich Plasma } \\ \text { PPP } & \text { Platelet-Poor Plasma } \\ \text { SEM } & \text { Standard Error of the Mean } \\ \text { SBB } & \text { Sudan Black B } \\ \text { SD } & \text { Standard Deviation } \\ \text { SOP } & \text { Standard Operating Procedure } \\ \text { FI } & \text { Fluorescence Intensity }\end{array}$

\section{References}

1. Ruggeri, Z.M.; Mendolicchio, G.L. Adhesion mechanisms in platelet function. Circ. Res. 2007, 100, 1673-1685. [CrossRef]

2. Bergmeier, W.; Hynes, R.O. Extracellular matrix proteins in hemostasis and thrombosis. Cold Spring Harb. Perspect. Biol. 2012, 4. [CrossRef] [PubMed]

3. Frenette, P.S.; Denis, C.V.; Weiss, L.; Jurk, K.; Subbarao, S.; Kehrel, B.; Hartwig, J.H.; Vestweber, D.; Wagner, D.D. P-Selectin Glycoprotein Ligand 1 (Psgl-1) Is Expressed on Platelets and Can Mediate Platelet-Endothelial Interactions in Vivo. J. Exp. Med. 2000, 191, 1413-1422. [CrossRef] [PubMed]

4. Eriksson, A.C.; Whiss, P.A. Measurement of adhesion of human platelets in plasma to protein surfaces in microplates. J. Pharmacol. Toxicol. Methods 2005, 52, 356-365. [CrossRef] [PubMed]

5. Varga-Szabo, D.; Pleines, I.; Nieswandt, B. Cell adhesion mechanisms in platelets. Arterioscler. Thromb. Vasc. Biol. 2008, 28, 403-412. [CrossRef] [PubMed] 
6. Ruggeri, Z.M. Platelets in atherothrombosis. Nat. Med. 2002, 8, 1227-1234. [CrossRef]

7. Stoll, G.; Kleinschnitz, C.; Nieswandt, B. Molecular mechanisms of thrombus formation in ischemic stroke: Novel insights and targets for treatment. Blood 2008, 112, 3555-3562. [CrossRef]

8. Yurchenco, P.D. Basement membranes: Cell scaffoldings and signaling platforms. Cold Spring Harb. Perspect. Biol. 2011, 3. [CrossRef]

9. Voss, B.; Rauterberg, J. Localization of collagen types I, III, IV and V, fibronectin and laminin in human arteries by the indirect immunofluorescence method. Pathol. Res. Pract. 1986, 181, 568-575. [CrossRef]

10. Polanowska-Grabowska, R.; Simon, C.G.; Gear, A.R. Platelet adhesion to collagen type I, collagen type IV, von Willebrand factor, fibronectin, laminin and fibrinogen: Rapid kinetics under shear. Thromb. Haemost. 1999, 81, 118-123.

11. Colman, R.W. Hemostasis and Thrombosis: Basic Principles and Clinical Practice; Lippincott Williams \& Wilkins: Philadelphia, PA, USA, 2006.

12. Martins Lima, A.; Martins Cavaco, A.C.; Fraga-Silva, R.A.; Eble, J.A.; Stergiopulos, N. From Patients to Platelets and Back Again: Pharmacological Approaches to Glycoprotein VI, a Thrilling Antithrombotic Target with Minor Bleeding Risks. Thromb. Haemost. 2019. [CrossRef] [PubMed]

13. Stefanini, L.; Bergmeier, W. Negative regulators of platelet activation and adhesion. J. Thromb. Haemost. 2018, 16, 220-230. [CrossRef]

14. Denis, C.V.; Wagner, D.D. Platelet adhesion receptors and their ligands in mouse models of thrombosis. Arterioscler. Thromb. Vasc. Biol. 2007, 27, 728-739. [CrossRef] [PubMed]

15. Massberg, S.; Schürzinger, K.; Lorenz, M.; Konrad, I.; Schulz, C.; Plesnila, N.; Kennerknecht, E.; Rudelius, M.; Sauer, S.; Braun, S.; et al. Platelet adhesion via glycoprotein Ilb integrin is critical for atheroprogression and focal cerebral ischemia: An in vivo study in mice lacking glycoprotein IIb. Circulation 2005, 112, 1180-1188. [CrossRef] [PubMed]

16. Gawaz, M. Platelets and Inflammation. Platelet Funct. 2005, 115-147. [CrossRef]

17. Li, Z.; Yang, F.; Dunn, S.; Gross, A.K.; Smyth, S.S. Platelets as immune mediators: Their role in host defense responses and sepsis. Thromb Res. 2011, 127, 184-188. [CrossRef]

18. Li, N. Platelets in cancer metastasis: To help the "villain" to do evil. Int. J. Cancer 2016, 138, 2078-2087. [CrossRef]

19. Xu, X.-X.; Gao, X.-H.; Pan, R.; Lu, D.; Dai, Y. A simple adhesion assay for studying interactions between platelets and endothelial cells in vitro. Cytotechnology 2010, 62, 17-22. [CrossRef]

20. Chiba, M.; Malik, S.W.; Specks, U. Microtiter plate immunoassay for the evaluation of platelet adhesion to fibronectin. J. Immunol. Methods 1996, 191, 55-63. [CrossRef]

21. Begley, C.G.; Ioannidis, J.P.A. Reproducibility in science: Improving the standard for basic and preclinical research. Circ. Res. 2015, 116, 116-126. [CrossRef]

22. Zhang, J.H.; Chung, T.D.Y.; Oldenburg, K.R. A Simple Statistical Parameter for Use in Evaluation and Validation of High Throughput Screening Assays. J. Biomol. Screen 1999, 4, 67-73. [CrossRef] [PubMed]

23. Francischetti, I.M.; Chiang, T.M.; Guimarães, J.A.; Bon, C. Role of the recombinant non-integrin platelet collagen receptor P65 on platelet activation induced by convulxin. Biochem. Biophys. Res. Commun. 2000, 270, 932-935. [CrossRef] [PubMed]

24. Francischetti, I.M.B.; Ribeiro, J.M.C.; Champagne, D.; Andersen, J. Purification, Cloning, Expression, and Mechanism of Action of a Novel Platelet Aggregation Inhibitor from the Salivary Gland of the Blood-sucking Bug, Rhodnius prolixus. J. Biol. Chem. 2000, 275, 12639-12650. [CrossRef] [PubMed]

25. Chavakis, T.; Boeckel, N.; Santoso, S.; Voss, R.; Isordia-Salas, I.; Pixley, R.A.; Morgenstern, E.; Colman, R.W.; Preissner, K.T. Inhibition of platelet adhesion and aggregation by a defined region (Gly-486-Lys-502) of high molecular weight kininogen. J. Biol. Chem. 2002, 277, 23157-23164. [CrossRef]

26. Podolnikova, N.P.; Yakubenko, V.P.; Volkov, G.L.; Plow, E.F.; Ugarova, T.P. Identification of a novel binding site for platelet integrins alpha IIb beta 3 (GPIIbIIIa) and alpha 5 beta 1 in the gamma C-domain of fibrinogen. J. Biol. Chem. 2003, 278, 32251-32258. [CrossRef]

27. Stevens, J.M. Platelet Adhesion Assays Performed Under Static Conditions. In Platelets and Megakaryocytes: Volume 1: Functional Assays; Gibbins, J.M., Mahaut-Smith, M.P., Eds.; Methods In Molecular Biology ${ }^{\mathrm{TM}}$; Humana Press: Totowa, NJ, USA, 2004; pp. 145-151. ISBN 978-1-59259-782-6. 
28. Dai, E.; Viswanathan, K.; Sun, Y.M.; Li, X.; Liu, L.Y.; Togonu-Bickersteth, B.; Richardson, J.; Macaulay, C.; Nash, P.; Turner, P.; et al. Identification of Myxomaviral Serpin Reactive Site Loop Sequences That Regulate Innate Immune Responses. J. Biol. Chem. 2006, 281, 8041-8050. [CrossRef]

29. Viswanathan, K.; Liu, L.; Vaziri, S.; Dai, E.; Richardson, J.; Togonu-Bickersteth, B.; Vatsya, P.; Christov, A.; Lucas, A.R. Myxoma viral serpin, Serp-1, a unique interceptor of coagulation and innate immune pathways. Thromb. Haemost. 2006, 95, 499-510. [CrossRef]

30. Blue, R.; Murcia, M.; Karan, C.; Jirousková, M.; Coller, B.S. Application of high-throughput screening to identify a novel alphaIlb-specific small- molecule inhibitor of alphaIlbbeta3-mediated platelet interaction with fibrinogen. Blood 2008, 111, 1248-1256. [CrossRef]

31. Podolnikova, N.P.; Yermolenko, I.S.; Fuhrmann, A.; Lishko, V.K.; Magonov, S.; Bowen, B.; Enderlein, J.; Podolnikov, A.V.; Ros, R.; Ugarova, T.P. Control of Integrin $\alpha \mathrm{IIb} \beta 3$ Outside-In Signaling and Platelet Adhesion by Sensing the Physical Properties of Fibrin(ogen) Substrates. Biochemistry 2010, 49, 68-77. [CrossRef]

32. Assumpção, T.C.F.; Alvarenga, P.H.; Ribeiro, J.M.C.; Andersen, J.F.; Francischetti, I.M.B. Dipetalodipin, a Novel Multifunctional Salivary Lipocalin That Inhibits Platelet Aggregation, Vasoconstriction, and Angiogenesis through Unique Binding Specificity for TXA2, PGF2 $\alpha$, and 15(S)-HETE. J. Biol. Chem. 2010, 285, 39001-39012. [CrossRef]

33. Crockett, J.; Newman, D.K.; Newman, P.J. PECAM-1 functions as a negative regulator of laminin-induced platelet activation. J. Thromb. Haemost. 2010, 8, 1584-1593. [CrossRef] [PubMed]

34. Calvo, E.; Tokumasu, F.; Mizurini, D.M.; McPhie, P.; Narum, D.L.; Ribeiro, J.M.C.; Monteiro, R.Q.; Francischetti, I.M.B. Aegyptin displays high-affinity for the von Willebrand factor binding site (RGQOGVMGF) in collagen and inhibits carotid thrombus formation in vivo. FEBS J. 2010, 277, 413-427. [CrossRef] [PubMed]

35. Ma, D.; Xu, X.; An, S.; Liu, H.; Yang, X.; Andersen, J.F.; Wang, Y.; Tokumasu, F.; Ribeiro, J.M.C.; Francischetti, I.M.B.; et al. A novel family of RGD-containing disintegrins (Tablysin-15) from the salivary gland of the horsefly Tabanus yao targets $\alpha \mathrm{Ilb} \beta 3$ or $\alpha \mathrm{V} \beta 3$ and inhibits platelet aggregation and angiogenesis. Thromb. Haemost. 2011, 105, 1032-1045. [CrossRef] [PubMed]

36. Hausmann, J.; Kamtekar, S.; Christodoulou, E.; Day, J.E.; Wu, T.; Fulkerson, Z.; Albers, H.M.H.G.; van Meeteren, L.A.; Houben, A.J.S.; van Zeijl, L.; et al. Structural basis of substrate discrimination and integrin binding by autotaxin. Nat. Struct. Mol. Biol. 2011, 18, 198-204. [CrossRef] [PubMed]

37. Fulkerson, Z.; Wu, T.; Sunkara, M.; Kooi, C.V.; Morris, A.J.; Smyth, S.S. Binding of Autotaxin to Integrins Localizes Lysophosphatidic Acid Production to Platelets and Mammalian Cells. J. Biol. Chem. 2011, 286, 34654-34663. [CrossRef]

38. Ma, D.; Assumpção, T.C.F.; Li, Y.; Andersen, J.F.; Ribeiro, J.; Francischetti, I.M.B. Triplatin, a platelet aggregation inhibitor from the salivary gland of the triatomine vector of Chagas disease, binds to TXA(2) but does not interact with glycoprotein PVI. Thromb. Haemost. 2012, 107, 111-123. [CrossRef]

39. Sachs, U.J.; Bakchoul, T.; Eva, O.; Giptner, A.; Bein, G.; Aster, R.H.; Gitter, M.; Peterson, J.; Santoso, S. A point mutation in the EGF-4 domain of $\beta(3)$ integrin is responsible for the formation of the Sec(a) platelet alloantigen and affects receptor function. Thromb. Haemost. 2012, 107, 80-87. [CrossRef]

40. Kim, K.; Lim, K.-M.; Shin, H.-J.; Seo, D.-B.; Noh, J.-Y.; Kang, S.; Chung, H.Y.; Shin, S.; Chung, J.-H.; Bae, O.-N. Inhibitory effects of black soybean on platelet activation mediated through its active component of adenosine. Thromb. Res. 2013, 131, 254-261. [CrossRef]

41. Assumpcao, T.C.F.; Ma, D.; Schwarz, A.; Reiter, K.; Santana, J.M.; Andersen, J.F.; Ribeiro, J.M.; Nardone, G.; $\mathrm{Yu}$, L.L.; Francischetti, I.M.B. Salivary antigen-5/CAP family members are $\mathrm{Cu}$ 2+-dependent antioxidant enzymes which scavenge $\mathrm{O} 2$ - and inhibit collagen-induced platelet aggregation and neutrophil oxidative burst. J. Biol. Chem. 2013, jbc.M113.466995. [CrossRef]

42. Podolnikova, N.P.; Yakovlev, S.; Yakubenko, V.P.; Wang, X.; Gorkun, O.V.; Ugarova, T.P. The Interaction of Integrin $\alpha \mathrm{Ilb} \beta 3$ with Fibrin Occurs through Multiple Binding Sites in the $\alpha \mathrm{IIb} \beta$-Propeller Domain. J. Biol. Chem. 2014, 289, 2371-2383. [CrossRef]

43. Ma, D.; Francischetti, I.M.B.; Ribeiro, J.M.C.; Andersen, J.F. The structure of hookworm platelet inhibitor (HPI), a CAP superfamily member from Ancylostoma caninum. Acta Crystallogr. F Struct. Biol. Commun. 2015, 71, 643-649. [CrossRef] [PubMed] 
44. Huang, Y.; Joshi, S.; Xiang, B.; Kanaho, Y.; Li, Z.; Bouchard, B.A.; Moncman, C.L.; Whiteheart, S.W. Arf6 controls platelet spreading and clot retraction via integrin $\alpha \operatorname{Ilb} \beta 3$ trafficking. Blood 2016, 127, 1459-1467. [CrossRef] [PubMed]

45. Newburg, D.S.; Tanritanir, A.C.; Chakrabarti, S. Lactodifucotetraose, a human milk oligosaccharide, attenuates platelet function and inflammatory cytokine release. J. Thromb. Thromb. 2016, 42, 46-55. [CrossRef] [PubMed]

46. Zafar, H.; Shang, Y.; Li, J.; David, G.A.; Fernandez, J.P.; Molina, H.; Filizola, M.; Coller, B.S. $\alpha$ IIb $\beta 3$ binding to a fibrinogen fragment lacking the $\gamma$-chain dodecapeptide is activation dependent and EDTA inducible. Blood Adv. 2017, 1, 417-428. [CrossRef] [PubMed]

47. Venturini, W.; Olate-Briones, A.; Valenzuela, C.; Méndez, D.; Fuentes, E.; Cayo, A.; Mancilla, D.; Segovia, R.; Brown, N.E.; Moore-Carrasco, R. Platelet Activation Is Triggered by Factors Secreted by Senescent Endothelial HMEC-1 Cells In Vitro. Int. J. Mol. Sci. 2020, 21, 3287. [CrossRef]

48. Wu, C.C.; Ko, F.N.; Huang, T.F.; Teng, C.M. Mechanisms-regulated platelet spreading after initial platelet contact with collagen. Biochem. Biophys. Res. Commun. 1996, 220, 388-393. [CrossRef]

49. Liu, C.Z.; Huang, T.F. Crovidisin, a collagen-binding protein isolated from snake venom of Crotalus viridis, prevents platelet-collagen interaction. Arch. Biochem. Biophys. 1997, 337, 291-299. [CrossRef]

50. Sheu, J.B.; Ko, W.C.; Hung, W.C.; Peng, H.C.; Huang, T.F. Interaction of thrombin-activated platelets with extracellular matrices (fibronectin and vitronectin): Comparison of the activity of Arg-Gly-Asp-containing venom peptides and monoclonal antibodies against glycoprotein IIb/IIIa complex. J. Pharm. Pharmacol. 1997, 49, 78-84. [CrossRef]

51. Sheu, J.R.; Yen, M.H.; Hung, W.C.; Lee, Y.M.; Su, C.H.; Huang, T.F. Triflavin inhibits platelet-induced vasoconstriction in de-endothelialized aorta. Arterioscler. Thromb. Vasc. Biol. 1997, 17, 3461-3468. [CrossRef]

52. Leng, L.; Kashiwagi, H.; Ren, X.D.; Shattil, S.J. RhoA and the function of platelet integrin alphaIIbbeta3. Blood 1998, 91, 4206-4215. [CrossRef]

53. Law, D.A.; Nannizzi-Alaimo, L.; Ministri, K.; Hughes, P.E.; Forsyth, J.; Turner, M.; Shattil, S.J.; Ginsberg, M.H.; Tybulewicz, V.L.; Phillips, D.R. Genetic and pharmacological analyses of Syk function in alphaIlbbeta3 signaling in platelets. Blood 1999, 93, 2645-2652. [CrossRef] [PubMed]

54. Sheu, J.R.; Hung, W.C.; Wu, C.H.; Ma, M.C.; Kan, Y.C.; Lin, C.H.; Lin, M.S.; Luk, H.N.; Yen, M.H. Reduction in lipopolysaccharide-induced thrombocytopenia by triflavin in a rat model of septicemia. Circulation 1999, 99, 3056-3062. [CrossRef] [PubMed]

55. Hsu, C.C.; Wu, W.B.; Huang, T.F. A snake venom metalloproteinase, kistomin, cleaves platelet glycoprotein VI and impairs platelet functions. J. Thromb. Haemost. 2008, 6, 1578-1585. [CrossRef] [PubMed]

56. Tseng, Y.-L.; Chiang, M.-L.; Huang, T.-F.; Su, K.-P.; Lane, H.-Y.; Lai, Y.-C. A selective serotonin reuptake inhibitor, citalopram, inhibits collagen-induced platelet aggregation and activation. Thromb. Res. 2010, 126, 517-523. [CrossRef] [PubMed]

57. Lima, A.M.; Wegner, S.V.; Martins Cavaco, A.C.; Estevão-Costa, M.I.; Sanz-Soler, R.; Niland, S.; Nosov, G.; Klingauf, J.; Spatz, J.P.; Eble, J.A. The spatial molecular pattern of integrin recognition sites and their immobilization to colloidal nanobeads determine $\alpha 2 \beta 1$ integrin-dependent platelet activation. Biomaterials 2018, 167, 107-120. [CrossRef]

58. Tseng, Y.-L.; Braun, A.; Chang, J.P.-C.; Chiang, M.-L.; Tseng, C.-Y.; Chen, W. Micromolar concentrations of citalopram or escitalopram inhibit glycoprotein VI-mediated and integrin $\alpha \mathrm{Ilb} \beta 3$-mediated signaling in human platelets. Toxicol. Appl. Pharmacol. 2019, 364, 106-113. [CrossRef]

59. Encyclopedia of Spectroscopy and Spectrometry-3rd Edition. Academic Press, 2016. Available online: https: //www.elsevier.com/books/encyclopedia-of-spectroscopy-and-spectrometry/lindon/978-0-12-803224-4 (accessed on 5 September 2020).

60. Gdovin, M.J.; Zamora, D.A.; Ravindran, C.R.M.; Leiter, J.C. Optical recording of intracellular pH in respiratory chemoreceptors. Ethn. Dis. 2010, 20, S1-33-S1-38.

61. Homolya, L.; Holló, Z.; Germann, U.A.; Pastan, I.; Gottesman, M.M.; Sarkadi, B. Fluorescent cellular indicators are extruded by the multidrug resistance protein. J. Biol. Chem. 1993, 268, 21493-21496.

62. Ramirez, C.N.; Antczak, C.; Djaballah, H. Cell viability assessment: Toward content-rich platforms. Expert Opin. Drug Discov. 2010, 5, 223-233. [CrossRef]

63. Nolte, M.A.; Kraal, G.; Mebius, R.E. Effects of fluorescent and nonfluorescent tracing methods on lymphocyte migration in vivo. Cytometry A 2004, 61, 35-44. [CrossRef] 
64. Membrane Fusion Technique, Part B, Volume 221-1st Edition. Available online: https://www.elsevier.com/ books/membrane-fusion-technique-part-b/abelson/978-0-12-182122-7 (accessed on 5 September 2020).

65. Gan, B.S.; Krump, E.; Shrode, L.D.; Grinstein, S. Loading pyranine via purinergic receptors or hypotonic stress for measurement of cytosolic pH by imaging. Am. J. Physiol. 1998, 275, C1158-C1166. [CrossRef] [PubMed]

66. Phillips, K.P.; Zhou, W.L.; Baltz, J.M. Fluorophore toxicity in mouse eggs and zygotes. Zygote 1998, 6, 113-123. [CrossRef] [PubMed]

67. Gdovin, M.J.; Zamora, D.A.; Ravindran, C.R.M.; Costanzo, M.C.; Leiter, J.C. Employing a pH Sensitive Fluorophore to Measure Intracellular $\mathrm{pH}$ in the In Vitro Brainstem Preparation of Rana catesbeiana. Open Zool. J. 2010. [CrossRef]

68. Oswald, M.W.; Hunt, H.H.; Lazarchick, J. Normal range of plasma fibrinogen. Am. J. Med. Technol. 1983, 49, 57-59. [PubMed]

69. Ozkan, P.; Mutharasan, R. A rapid method for measuring intracellular pH using BCECF-AM. Biochim. Biophys. Acta 2002, 1572, 143-148. [CrossRef]

(C) 2020 by the authors. Licensee MDPI, Basel, Switzerland. This article is an open access article distributed under the terms and conditions of the Creative Commons Attribution (CC BY) license (http://creativecommons.org/licenses/by/4.0/). 